\title{
Geological and hydrogeochemical properties of geothermal systems in the southeastern region of Turkey
}

\author{
A. Baba ${ }^{\mathrm{a}, *}$, F. Şaroğlu ${ }^{\mathrm{b}}$, I. Akkuş ${ }^{\mathrm{b}}$, N. Özel ${ }^{\mathrm{c}}$, M.İ. Yeşilnacar ${ }^{\mathrm{d}}$, M.T. Nalbantçılar ${ }^{\mathrm{e}}$, M.M. Demir ${ }^{\mathrm{a}}$, \\ G. Gökçen ${ }^{\mathrm{a}}$, Ş. Arslan ${ }^{\mathrm{e}}$, N. Dursun ${ }^{\mathrm{d}}$, T. Uzelli ${ }^{\mathrm{a}}$, H. Yazdani $^{\mathrm{a}}$ \\ a Izmir Institute of Technology, İzmir, Turkey \\ ${ }^{\mathrm{b}}$ General Directorates of Mineral Research and Exploration (MTA), Ankara, Turkey \\ ${ }^{\mathrm{c}}$ GAP Regional Development Administration, Şanluurfa, Turkey \\ ${ }^{\mathrm{d}}$ Harran University, Şanluurfa, Turkey \\ ${ }^{\mathrm{e}}$ Batman University, Batman, Turkey
}

\section{A R T I C L E I N F O}

\section{Keywords:}

Geothermal resources

Geothermal usage

Hydrogeochemistry

GAP region

Turkey

\begin{abstract}
A B S T R A C T
The Anatolia region is one of the most seismically active regions in the world. It has a considerably high level of geothermal energy potential thanks to its geological and tectonic settings. The Southeastern Anatolia Region (GAP) is located in the south of Bitlis-Zagros Suture Zone (BZSZ) which is in the Arabian foreland. During the neotectonic period, the folded structures have been developed under the influence of tectonic compression from the Upper Miocene in the GAP Region where it is closely related to active tectonics. These tectonic activities produce more geothermal resources. Few studies have been carried out in this region for geothermal energy. Limited portions of the geothermal resources have been used both for thermal tourism and greenhouses in the GAP region. The aim of this study is to determine geological, tectonic and hydrogeochemical properties of a geothermal system in the GAP Region. The result indicates that the surface temperatures of geothermal fluids are from 20 to $84.5^{\circ} \mathrm{C}$ A large number of abandoned oil wells, whose temperature reaches $140{ }^{\circ} \mathrm{C}$, are found in the region. Also, hydrogeochemical results show that deep circulated geothermal fluids are enriched with $\mathrm{Na}-\mathrm{Cl}$ and shallow geothermal system fluids have $\mathrm{Na}-\mathrm{HCO}_{3}$ and $\mathrm{Ca}-\mathrm{SO}_{4}$ characters because of cold water mixing and water-rock interaction. Cold waters are generally of $\mathrm{Ca}-\mathrm{Mg}-\mathrm{HCO}_{3}$ and $\mathrm{Ca}-\mathrm{HCO}_{3}$ type. Cation geothermometers were used for determining reservoir temperature of the geothermal resources in the region. The results show that the reservoir temperature of these geothermal resources ranges from $50{ }^{\circ} \mathrm{C}$ to $200{ }^{\circ} \mathrm{C}$. The isotope data (oxygen-18, deuterium and tritium) suggests that geothermal fluid is formed by local recharge and deep circulation.
\end{abstract}

\section{Introduction}

Energy demand is one of the main challenges of most world countries today. The most important reasons for this are the increase in population growth, industrialization and living standards. A large part of the energy requirement, which shows a rapid increase all over the world, can be supplied by fossil fuels and renewable energy. It is expected that fossil fuels will be consumed in a short period of time and that they will be replaced by renewable energy sources. In recent years, the importance of the development of new energy sources has become paramount. The most important of this new energy is renewable energy sources. The geothermal energy among renewable energy sources will be the most important energy source of many countries in the near future (Baba, 2015a; and 2015b; Baba et al., 2015a, b). The distribution of geothermal areas in Turkey roughly coincides with the distribution of the fault systems, and young volcanism. Geothermal exploration studies in Turkey began in 1962 by the General Directorate of Mineral Research and Exploration (MTA). There is a total of about 1500 thermal and mineral water spring groups distributed all over the country. The highest $\left(295^{\circ} \mathrm{C}\right)$ bottom hole temperatures have been measured in the center of Turkey (Şimsek et al. (2002)). The installed capacity is 3322 $\mathrm{MW}_{\mathrm{th}}$ for direct use (heating) and $1100 \mathrm{MW}_{\mathrm{e}}$ for electricity generation (Akkuş, 2017). Energy, one of the most pressing needs of Turkey, is also the key element in the GAP region. The region's energy production capacity is larger than its consumption. To make use of this, many projects are being implemented to further enlarge the region's energy production capacity. Geothermal resources are of extreme importance for Turkey, especially for improving rural areas of the GAP region.

\footnotetext{
* Corresponding author.

E-mail address: alperbaba@iyte.edu.tr (A. Baba).
} 
There are many publications in the literature about the geology, natural resources and active tectonics of the Southeastern Anatolia Region. Detailed studies on the geology and young tectonics of the region have been mainly carried out by MTA, Turkish Petroleum Corporation (TPAO), and universities to varying extent. Most studies are carried out on oil production that is one of the important energy resources of Turkey. Studies on the natural resources of the region have been carried out by various domestic and foreign companies since the last century. However, studies on the geothermal resources of the region are limited. Few geological, hydrogeochemical studies and geophysical surveys have been carried out in some geothermal regions (Özel and Bekişoğlu, 2002; Baba et al., 2015a). No comprehensive research to determine the relationship between the geodynamics of the region and its development of a geothermal system has been carried out.

The aim of this study is to determine, the geological, neotectonic and hydrogeochemical characteristics of the geothermal fields in Southeastern Anatolia which is located within one of the important tectonic zones of Turkey.

\section{Study area}

The Southeastern Anatolia Project (with its Turkish acronym GAP) is a significant regional development program that reveals the regional potential of Turkey and contributes to the national economy in real terms with the welfare it is responsible for. It is a project that sets local initiatives in motion and it has attainable targets. The GAP is the largest regional development project ever in Turkey and also one of the largest ones worldwide (GAP, (2014)). The GAP covers the Southeastern Anatolia Region comprising nine administrative provinces (Adiyaman, Batman, Diyarbakır, Gaziantep, Kilis, Mardin, Siirt, Şanlıurfa and Şrnak) (Fig. 1). The geographical area and population of the region corresponds to about $10 \%$ of country's total area and population. The GAP Region is 75,358 square kilometers and constitutes $9.7 \%$ of the total area of Turkey. About 20 percent of the 8.5 million hectares of irrigable land in Turkey is located in the GAP Region.

\section{Geological settings of the GAP region}

The GAP Region is very rich in terms of oil, asphaltite and several industrial raw materials. For this reason, a number of geological studies have been carried out for different purposes in the region (Yölmaz and Yiğitbaş, 1990; Günay et al., 1990; Şengör, A.M.C. and Burke, K., 1978; Şengör et al., 1984; Şengör, 1980; Şaroğlu, 1985; Pearce et al., 1990; Akkuş et al., 2005; Şaroğlu and Emre, 1987; Ercan et al., 1991). The geological framework has been an important for interpreting, finding and locating geothermal systems without any surface manifestations. Stratigraphic sequences, cap rock, reservoir rock, permeability and porosity, fluid dynamics, fault-fracture relations with regional and/or local stress regime, heat flows in the lithosphere are requisite parameters for developing a favorable geothermal system.

From a global scale view point, plate tectonics control the thermal condition of the crust and geothermal systems shape by large-scale movements of tectonic plates. Likewise, the geothermal systems of Turkey fall within the active Alpine-Himalayan Fold and Thrust Belt where the collision of the Africa and Eurasia plates and also the closure of the Tethys Ocean takes place today (Bozkurt, 2001). The Anatolian Plate has rock assemblages that represent geological processes that last from about two billion years ago to the present day. The area is divided into regions and subzones according to the lithology, magmatism, tectonic, paleogeography and metamorphism of the rock assemblages. Southeastern Anatolia is also named as the Arabic Platform, the Arabian Plate, edge folds etc. by numerous researchers according to the geodynamics properties of Anatolia (Sungurlu, 1974; Ketin, 1983; Şengör, 1980; Perinçek, 1980; Perinçek and Özkaya, 1981; Şengör and Yölmaz, 1981; Şengör et al., 1985; Şaroğlu, 1985; Şaroğlu and Yölmaz, 1987; Y1lmaz, 1993; Seyitoğlu et al., 2017).

According to rock assemblages and geodynamic processes, Southeastern Anatolia bears the traces of the continent-continent collision with the Anatolian Plate, which was brought together with the suture zone existing in the northern part of the Arabian Plate of rock assemblages. In other words, maps made in relation to the north border of Southeast Anatolia, namely the rocky community, the suture zone, the movement of the different plates and the deformation in the neotectonic period (Perinçek, 1979).

During the Late Mesozoic, closure of the Tethyan Ocean around

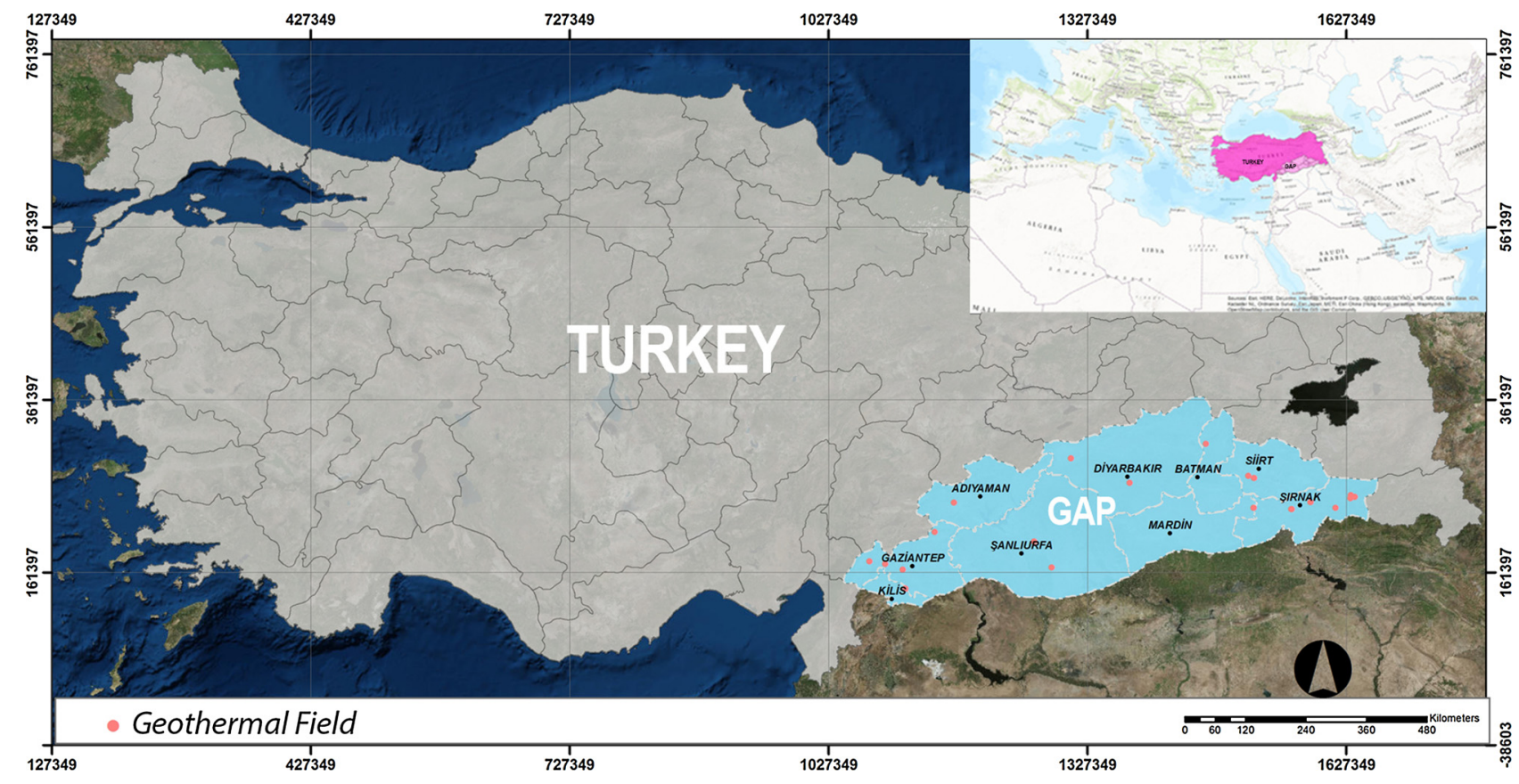

Fig. 1. Location map of study area. 


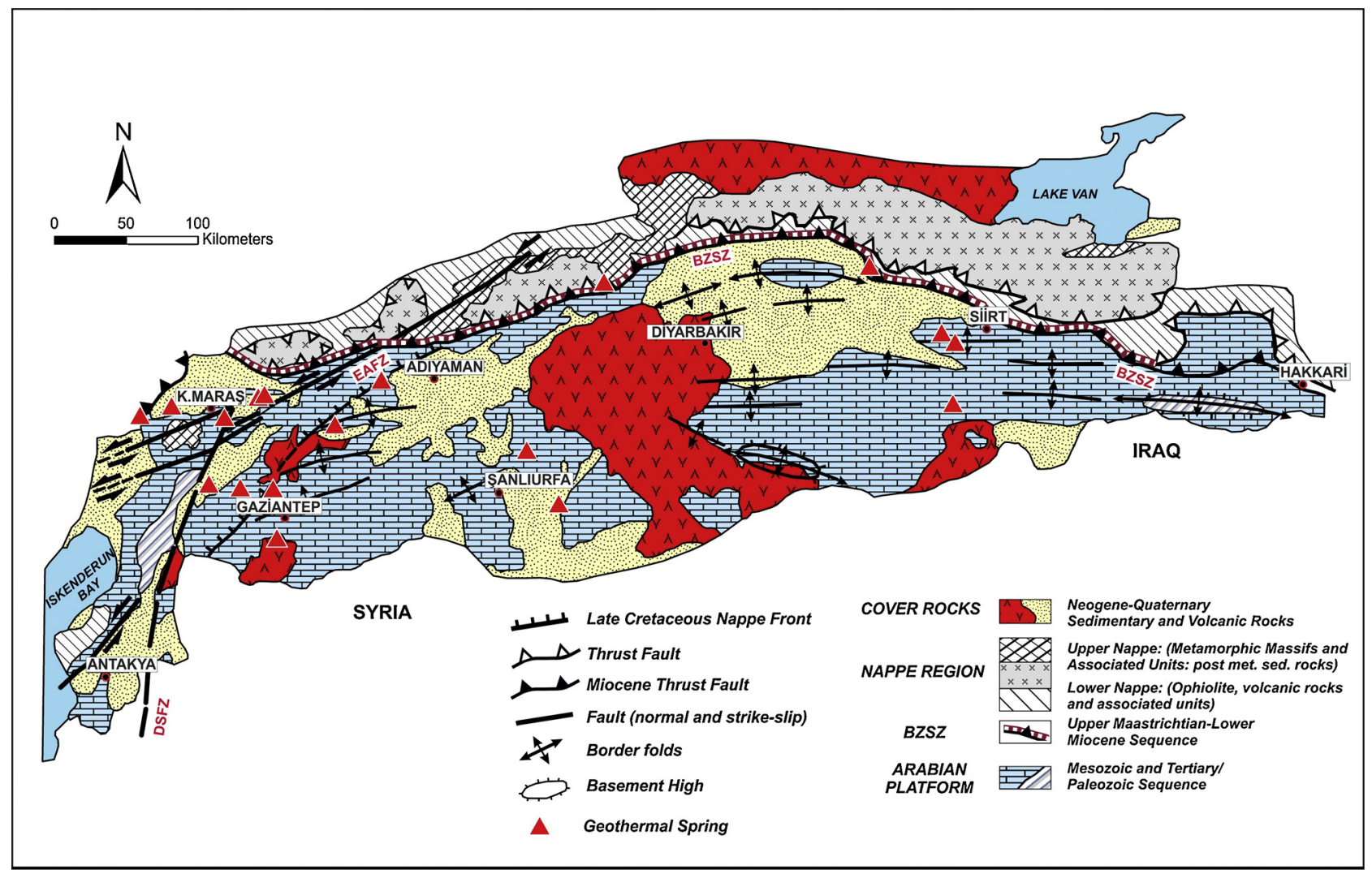

Fig. 2. Geological map of GAP region (modified from Y1lmaz, 1993 and Günay et. al., 1990).

Eastern Pontide Arc and the Taurid block of the Arabian plate with the Bitlis-Pütürge micro-continent and related magmatic arc were primarily controlled mechanisms for the region (Dilek and Sandvol, 2009). In the Early Miocene, the collision process around the Bitlis Zagros Suture Zone (BZSZ), formed the melange and flysch deposits of the Nappe region (Yllmaz, 1993). With the formation of the East Anatolian Accretionary Complex accompanied by the fluvial sedimentation in the ramp basins, the morphology of East Anatolia had a plateau-like character.

The present-day morphology of Eastern Anatolia has three terranes mainly. These are the Para-autochthonous Arabian Platform (foreland) in the south, the Bitlis Massif in the center and the Pontid Belt in the north. These terranes are separated by a foreland-type thrusting-folding belt, the Bitlis-Zagros Suture Zone, and the collision-related Pontide Suture Zone. The study area is located in southeastern Anatolia so the GAP area corresponds to the region between the Bitlis Massif, the BZSZ and the Arabian foreland (Fig. 2). In the south of the GAP area there is an almost continuous stratigraphic sequence of shelf sediments of $\mathrm{Pa}$ laeozoic to Miocene age, and in the north, the rocks of the Bitlis Massif, an allochthonous terrain of Palaeozoic metamorphic rocks and metasediments (Binboğa-Keban met., Malatya met., Bitlis-Pötürge met.) can be seen (Hall, 1976; Pearce et al., 1990). Between the Bitlis Massif and the Arabian foreland, several rock assemblages have been identified. These assemblages are the member of a complex and complicated collision zone (Nappe region), and contain Late Cretaceous ophiolitic and island arc related rock groups and also mafic lavas related to Middle Eocene pelagic chalks (Robertson and Aktaş, 1984; Pearce et al., 1990; Y1lmaz, 1993; Günay et al., 1990).

The rocks are dated from Precambrian to Quaternary outcrops in the GAP Region. Cover rocks are generally consist of Quaternary-Neogene sedimentary deposits and volcanic products. The most common observations of the geological units are Cretaceous limestones (Mardin Group), Paleocene clay-silt levels of the Germav Formation belonging to the Şırnak Group, Gercüş mudstones belonging to the Midyat Group, Hoya and Gaziantep limestones and the Miocene Lice and Şelmo formations (Fig. 3). Older rock groups are observed in limited areas (Derik and Hazro anticlines) as at the core parts of worn anticlines (Ketin, 1983). Germav, Lice and Şelmo formations, which are widespread in the region, act as a caprock of the GAP geothermal system. The reservoir rocks are limestones which belong to Mardin and Midyat. It can not be predicted spreads of units, which are exposed to extreme tectonism, under the Cretaceous Mardin Group.

\section{Neotectonic properties of the GAP region}

The tectonic activity of Anatolia is controlled by a continental collision of the African and Eurasian plates with the deformation of intracontinental convergence and tectonic-escape related movements. In addition to collision movements, the dextral North Anatolian Fault Zone (NAFZ), the sinistral East Anatolian Fault Zone (EAFZ) and Aegean-Cyprian Arc are the major tectonic structures that shape the neotectonic properties of the Anatolian Region. The Aegean-Cyprian Arc coincides with the area where the subduction process between Anatolian and African plates takes place. The EAFZ and NAFZ intersect along the Karlıova region and form an intra-continental triple junction structure and that tectonic structure shapes and influences deformation in the Anatolian Plate. As a result of these mechanisms, structural elements and associated basin formation and deformation, four different neotectonic provinces have been defined in the Anatolian Plate: the East Anatolian Contractional Province (EACP), the North Anatolian Province (NAP), the Central Anatolian (Ova) Province (CAOP), and the West Anatolian Extensional Province (WAEP) (Şaroğlu, 1985, 1987; Şengör and Y1lmaz, 1983; Sengör et al., 1985; Bozkurt and Mitwede (2001); Fig. 4).

Around the study area, a minimum of three tectonic different regimes occur between Late Palaeozoic, Cretaceous-Eocene, Lower 


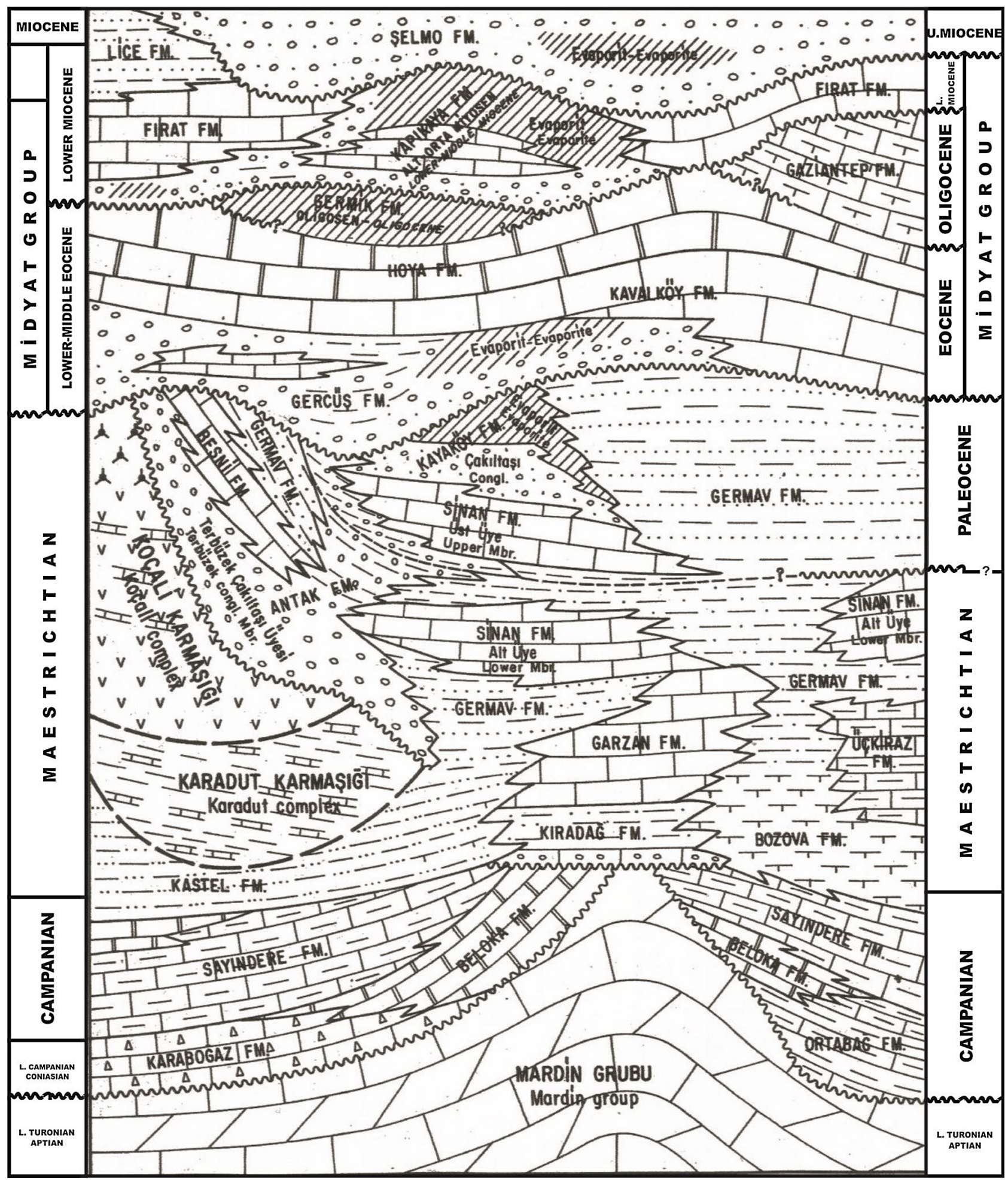

Fig. 3. Schematic cross-section of allochthonous and para-allochthonous stratigraphic units of correlation around GAP area (Perinçek, 1980).

Miocene-Holocene times and Post-Miocene activity (Yölmaz and Yiğitbaş, 1990). All the assemblages mentioned by the tectonic activity caused by the collision of Eurasian and Arabian plates. Collision forms several folds, faults, nappes and klippe structures with four known different local thrusting events after Eocene time (Fig. 5).

The deformation of the Eastern Anatolian Region is also controlled by conjugate strike-slip faults of EAFZ and NAFZ with collision related $\mathrm{N}-\mathrm{S}$-trending fissures. These fissures are responsible for volcanic activity in the East Anatolian Contractional Province (EACP). The volcanic activity is thought to have begun in Late Miocene as a result of a continental collision. For this reason, EACP has various types of faults and tectonic structures (Pearce et al., 1990). The first type of faults is generally SE-trending with a right lateral strike-slip character. The second group faults are characterized by a NE- to NNE- trending, left lateral strike-slip. Faults of the BZSZ, other thrust faults such as the fault bounding the northern margin of the Muş Basin and E-W trending ramp structures form the third group (Şaroğlu, 1985, 1987; Pearce et al., 1990). 


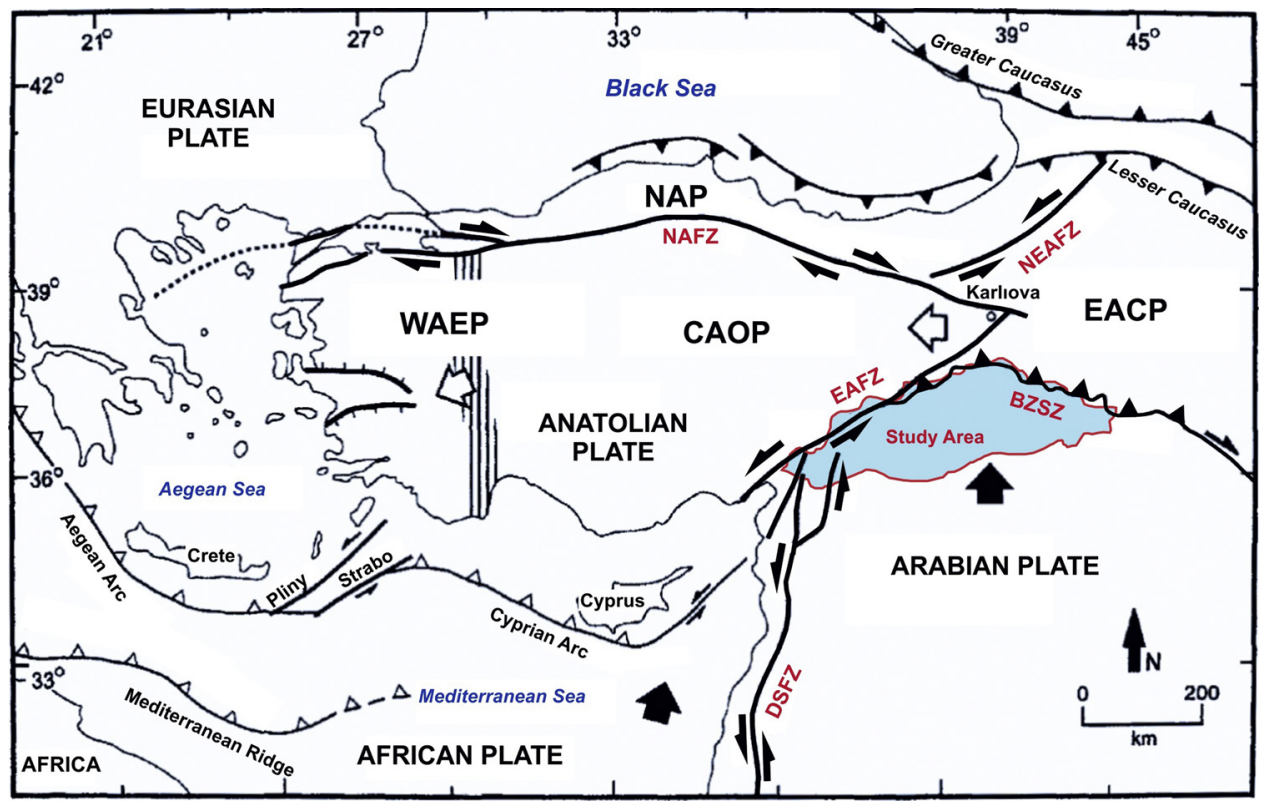

Fig. 4. Simplified tectonic map of Anatolia showing major neotectonic structures and neotectonic provinces (modified from Bozkurt, 2001). DSFZ = Dead Sea fault zone; EAFZ = East Anatolian Fault Zone, NAFZ $=$ North Anatolian Fault Zone; NEAFZ $=$ Northeast Anatolian Fault Zone, BZSZ = Bitlis-Zagros Suture Zone, NAP = North Anatolian Province, $\mathrm{CAOP}=$ Central Anatolian Ova Province, WAEP $=$ West Anatolian Extensional Province, EACP $=$ East Anatolian Contractional Province. The hatched area shows the transition zone between the western Anatolian extensional province and the central Anatolian "ova" province (Şaroğlu, 1985, 1987; Şengör, 1980; Şengör and Yölmaz, 1983 Şengör et al., 1984, 1985).

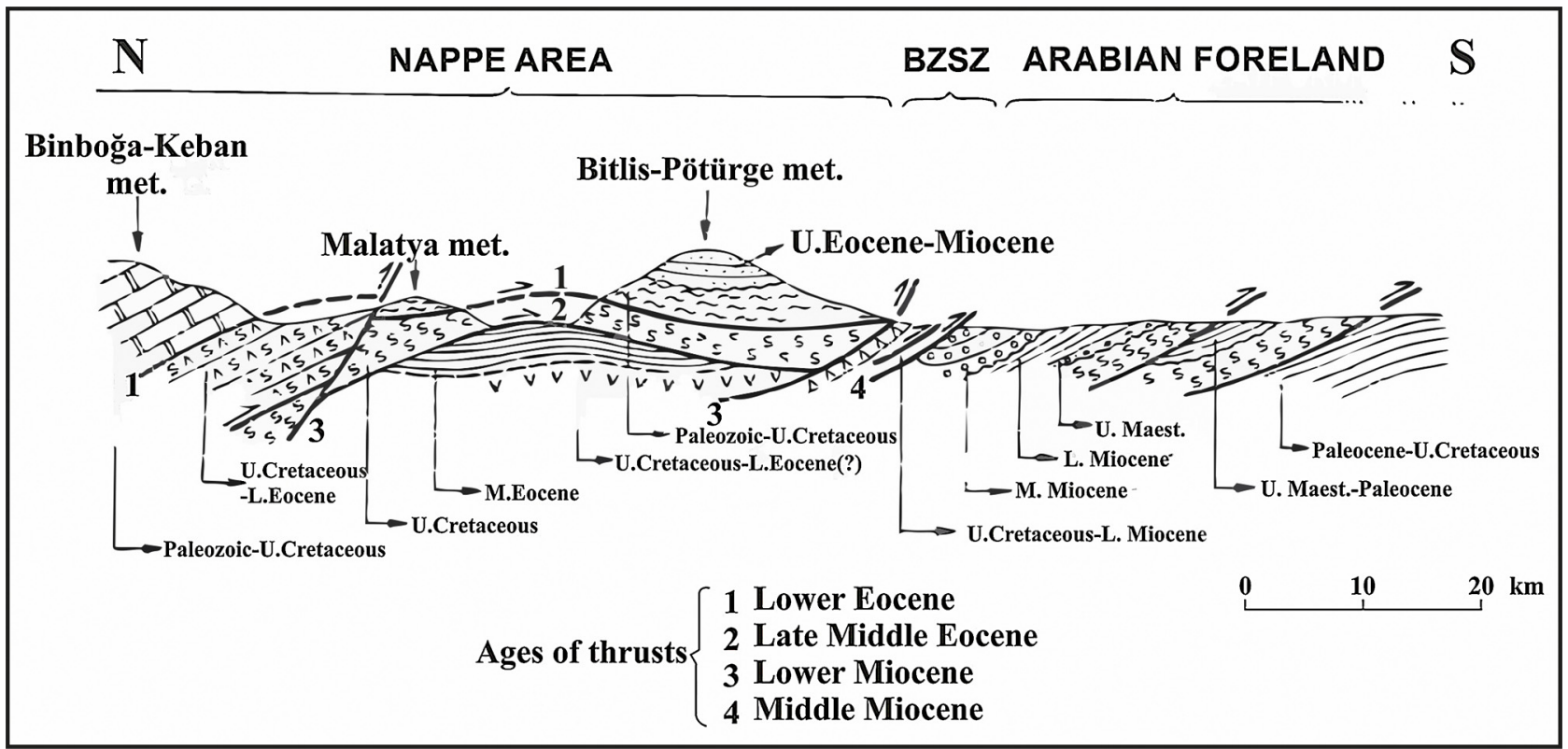

Fig. 5. Schematic section across to Southeastern Anatolia summarizing tectonic units with the possible age of thrusting events (Yölmaz and Yiğitbaş, 1990).

The GAP region contains several tectonic structures such as thrust faults and nappes. These tectonic structures are surrounded by the BZSZ in the north. In the field studies, structures were observed and identified but it is quite difficult to group them because of a complex tectonic structure. The distribution of geothermal springs of the GAP region roughly coincides with the distribution of the fault systems.

There are several geothermal resources present around the Adiyaman and Gaziantep provinces. The main tectonic structures of that area are the EAFZ in the west and the BZSZ in the north. Geothermal springs of Çörmük, Besni (Adıyaman), Araban, Kartalköy (Gaziantep) tectonically formed by collision related fold axes/anticlines and thrust faults with locally intersecting strike-slip faults between the EAFZ and the Halfeti Fault (Şaroğlu and Emre, 1987; Seyitoğlu et al., 2017). In addition to these faults, N-S directed tension cracks and fissures have been observed around the geothermal springs. Çermik (Batman), Beytüşşebap, Besta (Şırnak) geothermal springs were also formed under influence of the compressional tectonic regime and have a direct connection with reverse/thrust faults.

Intersecting faults are important for permeability and geothermal activity. In several studies numerous relation between faults and the formation of geothermal springs have been defined (Şimsek (1997); Şimsek et al. (2002); Faulds et al., 2010; Faulds and Hinz, 2015; Uzelli et al., 2017). The Taşlıdere (Batman), Ilısu (Mardin), Kabahaydar (Şanlıurfa), Billoris (Siirt) geothermal springs formed around the zones of accommodation are created by intersected faults. The observed folds generally have $\mathrm{E}-\mathrm{W}$ trendings and have a direct relationship with $\mathrm{N}-\mathrm{S}$ directed tension cracks and shear cracks with dominant are N-S, NE-SW and NW-SE directions (Fig. 6.).

As a result of local extension; small rift structures, N-S trending normal faults and The Harran and The Akçakale Grabens, are distinct structures in the region. In the Şanliurfa province, the Karaali geothermal field is a result of faults of the extensional regime. N-S directed normal faults control the geothermal fluid circling around the Akçakale graben. These normal faults were possibly formed by the same tectonic 


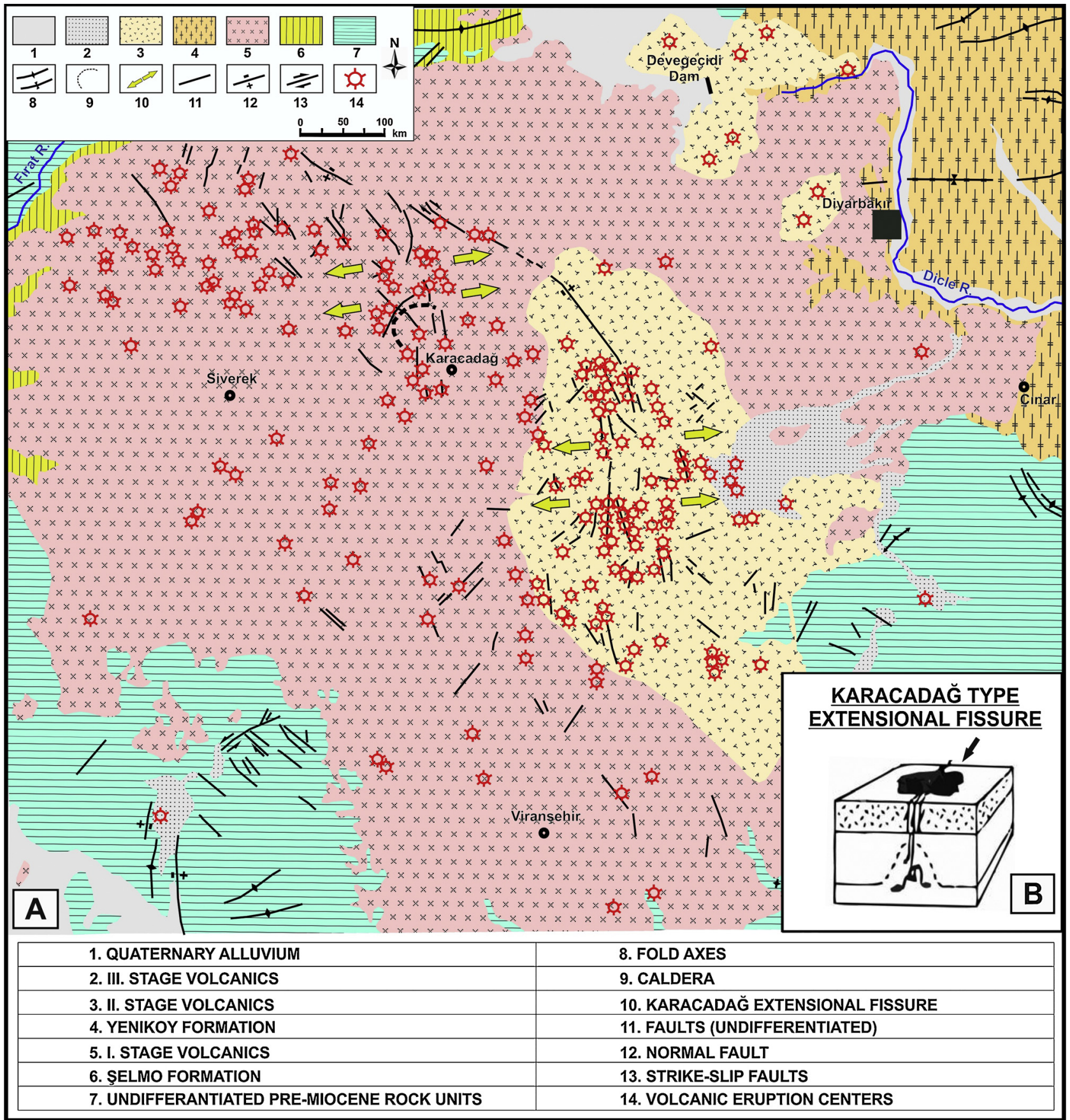

Fig. 6. a) Geological map of Karacadağ and surrounding area (modified from Şaroğlu and Emre, 1987), b) Model of Karacadağ type rifting structure (Yılmaz, 1981; Şengör and Burke, 1978).

processes within collision related fissures and cracks.

The volcanism around the study area has been studied by different researchers (Haksal, 1981; Şaroğlu and Emre, 1987; Pearce et al., 1990; Ercan et al., 1991) including studies of petrography, origin, petrology, and geochemistry. The only volcanism in the Southeast identifiable that can be correlated to geothermal systems is observed in the Neotectonic period. This volcanism, which has been distributed from the west to the east part of the region, is concentrated in the Karacadağ region between Diyarbakır and Şanlıurfa. The lava flows observed in other areas of the region are covered with sedimentary rocks of a limited thickness. For this reason, the lava outcrops outside of Karacadağ are called "the Yildızeli Basalts" but they are assumed to belong to the same volcanic activity.
The Karacadağ Volcanics on the Arabian Platform can be seen in an area of about $10,000 \mathrm{~km}^{2}$ between Diyarbakır, Şanlıurfa and Mardin (See Fig. 2). During the volcanic activity, the same composition of basaltic lavas and pyroclastics have surfaced. Volcanism has not maintained its entire activity uniformly. The volcanism is exposed in such a way that the three activity stages and each activity stage can be divided into several phases (Şaroğlu and Emre, 1987; Fig. 6).

Fissures and normal faults in the Arabian foreland are major structures that control the volcanic activity. In the west of Diyarbakır, the NW-SE trending right lateral North Karacadağ Fault (Emre et al., 2012) and the N-S trending Karacadağ Extensional Fissure (Şengör et al., 1985; Saroğlu and Emre, 1987; Ercan et al., 1991) are located near the Karacadağ $(1957 \mathrm{~m})$, a low shield volcano located in the 
Arabian foreland (see Fig. 6). Volcanic products are mainly of a basaltic character and erupted along $\mathrm{N}-\mathrm{S}$ trending fissures and craters formed under the influence of the neotectonic period tectonic regime (Şaroğlu, 1985 and 1987; Pearce et al., 1990). Especially, the northwestern part of the Karacadağ is the important region in the GAP where the volcanism affects surface morphology with craters and domes. Because of these features, volcanic activity seems to be regional but geothermal manifestations may be local. Today, as we look from the continental scale view point, the GAP region faces the compressional tectonic regime and deformation occurs along the Bitlis-Zagros Suture Zone. Reverse and thrust faulting with $\mathrm{E}-\mathrm{W}$ directional main faults cause the formation of smaller N-S extensional tear fault like tectonic structures. These faults, which cause the regional and/or local extension, can create deeper cracks through the surface, facilitating the circulation of the hot water that may come from the depth. In the field observations, the direction of the opening cracks observed in the areas where the hot springs emerge, also supports this interpretation.

\section{Geothermal resources in the GAP region}

Numerous studies have been carried out on geology, tectonics and oil in the Southeastern Anatolian Region (Wilson and Krummenacher (1957); Bolgi, 1964; Rigo De Righi and Cortesini, 1964; Schmidt, 1964; Sungurlu, 1972 and 1974; Perinçek, 1979; Yölmaz, 1981; Perinçek and Özkaya, 1981; Ketin, 1983; Şengör and Yölmaz, 1981; Yazgan, 1984; Yazgan and Chessex, 1991; Turan, 1995). Studies on the properties of geothermal resources are rare in the past (Erzenoğlu and Özeke, 1984; Yıcel, 1989a; and 1989b; Uzel and Kalkan., 1992; Eşder and Tımer, 1997; Eşder and Buzkiran (1998); Ertırk, 1999; Özel and Bekişoğlu, 2002; Doğdu and Kirmizitaş (2006); Akkuş et al., 2005; Mertoğlu, 2010; Özel, 2010). Much of the work was done by the MTA. However, most of the previous studies were aimed only at determining the situation of the geothermal resources. Recently, some studies have been carried out in the region to find out how to better utilize geothermal energy. Today, the importance of geothermal resources has increased and investments in geothermal energy have also started. Şanlıurfa (Karaali) has limited geothermal energy that is used for thermal tourism and greenhouses. Also, geothermal resources are utilized simply for thermal tourism purposes in Diyarbakır (Çermik), Adıyaman (Çelikhan), Şırnak (Hısta, Besta Meryem, Nasrafan ve Zümrütdağ) Batman (Taşlıdere), Siirt (Billoris and Lif) and Mardin (Dargeçit). Geothermal resources are not used effectively in Adıyaman (Tilek, Rötükan, Bistikan ve Bigar) and Gaziantep (Kartalköy). Locations of geothermal resources in the GAP region are shown in Fig. 7.

\section{Materials and methods}

For the investigation and comparison of the hydrogeochemical characteristics in the GAP region, twenty geothermal springs and five cold water samples were collected from 2014 to 2015 in the study area. The concentrations of major ions, some heavy metals and isotopes were determined in the water samples. During the field surveys, some physical parameters of the geothermal fluid, including temperature $\left({ }^{\circ} \mathrm{C}\right)$, $\mathrm{pH}$, and electrical conductivity $(\mathrm{EC}, \mu \mathrm{S} / \mathrm{cm})$, were measured iN-Situ with a Hach HQ40D portable multimeter. The $\mathrm{pH}$-meter was calibrated with $\mathrm{pH} 4, \mathrm{pH} 7$, and $\mathrm{pH} 10$ buffer solutions before commencing fieldwork. In order to determine the variation in the mineral concentration of the water samples, they were collected in unused 50, 500, and $1000 \mathrm{ml}$ hard-plastic bottles. Water samples were filtered using disposable cellulose acetate syringe filters of $0.45 \mu \mathrm{m}$. To prevent the formation of heavy metal complexes with oxygen, samples were acidified with $\mathrm{HNO}_{3}$ to $\mathrm{pH} \backslash 2$. Acidified samples were analyzed for major and trace elements with an ICP-MS (inductively coupled plasma mass spectrometer) at ACME Labs (Canada). A non-acidified sample was used for anion analysis. Chlorine and $\mathrm{HCO}_{3}{ }^{-}$were determined volumetrically and $\mathrm{SO}_{4}{ }^{2-}$ by a gravimetric method at the İmir Institute of
Technology (IIT). Also, $\mathrm{SiO}_{2}$ was determined by spectrophotometric at the IIT. Determination of deuterium $\left({ }^{2} \mathrm{H}\right)$, oxygen-18 $\left({ }^{18} \mathrm{O}\right)$ and tritium $\left({ }^{3} \mathrm{H}\right)$ was carried out at Hacettepe University.

\section{Hydrogeological and hydrogeochemical properties of the investigation area}

The Cretaceous Mardin Group and the Eocene Midyat Group limestones constitute the main reservoirs of geothermal systems due to their distribution and thickness in the GAP region. The Germav shales belonging to the Cretaceous Şırnak Group, Miocene Lice, and Şelmo formations are the main cap rocks of the geothermal system. The Mesozoic aged carbonates found below the defined units and clayey levels observed among them are considered as a secondary reservoir which creates secondary permeability within them and thus pathways for deep circulation. One of the criteria used in this distinction is that the rock units considered at the secondary level and are covered by younger units, are exposed in limited places due to erosion streaks and different tectonic events, and their underground continuity cannot be interpreted.

The Karacadağ volcanism is a regional heat source of the geothermal systems in the GAP region. Volcanic structures like domes, maars and lava flows are morphological results of the energy stored at depth. So these weakness zones also play an important role for geothermal activity. Volcanic activity has caused deformation in rocks and opening cracks like structures create fractured hydrogeological systems at shallow depths. Today, the N-S directional cracks are the main structural element which facilitates fluid transport within the geothermal resources to the surface, also with increasing depth, hydraulic conductivity declines and aquifer characteristics such as water chemistry, thickness and propagation become more important. At this stage, geophysical studies and the presence of drillholes are critical.

The GAP Region is rich in terms of geothermal potential. However, drilling has not been carried out in geothermal areas except for the Karaali geothermal field. Most of the shallow drillholes were drilled for irrigation in karstic limestone. However, this region is very important for oil production. The TPAO and some international companies own many wells which reach up to $3000 \mathrm{~m}$ in depth in this region. In most of these wells, low $\left(41-56^{\circ} \mathrm{C}\right)$ and medium-temperature $\left(137^{\circ} \mathrm{C}\right)$ geothermal fluids were obtained.

\subsection{Physical properties of water}

In the geothermal locations shown in Fig. 7 in the GAP region, water samples were collected for hydrogeochemical investigations in April 2015. A host of physical and chemical analysis was performed on the samples. According to the results, the surface temperature and the electrical conductivity (EC) of hot fluids range from 22.5 to $62.2^{\circ} \mathrm{C}$ and from 513 to $2390 \mu \mathrm{S} / \mathrm{cm}$, respectively (Table 1). Samples from cold water sources were collected near the hot springs. Temperature and EC values for these cold waters vary between 9.0 and $15.9^{\circ} \mathrm{C}$ and $177.8-577.0 \mu \mathrm{S} / \mathrm{cm}$, respectively (Table 1 ). The high surface temperatures are seen in the Belkısana (Hısta) and Zümrüt geothermal fields in the Şırnak Region. The fluid from the Kozluk-Taşlidere (Batman) geothermal field which emerges as artesian water has the highest wellhead temperature $\left(84.5^{\circ} \mathrm{C}\right)$ and electrical conductivity $(18,550 \mu \mathrm{S} / \mathrm{cm})$. The geothermal fluid, which emerges as an artesian flow from oil drilling in Kozluk-Taşlidere, is used by the local people. This geothermal fluid comes from $2400 \mathrm{~m}$ depth.

\subsection{Chemical properties of the water resources}

According to the results of chemical analysis, water resources of the GAP region have a different anion and cation composition. The ionic composition of water is used to classify it into ionic types based on the dominant cation and anion, expressed in milliequivalents per liter 


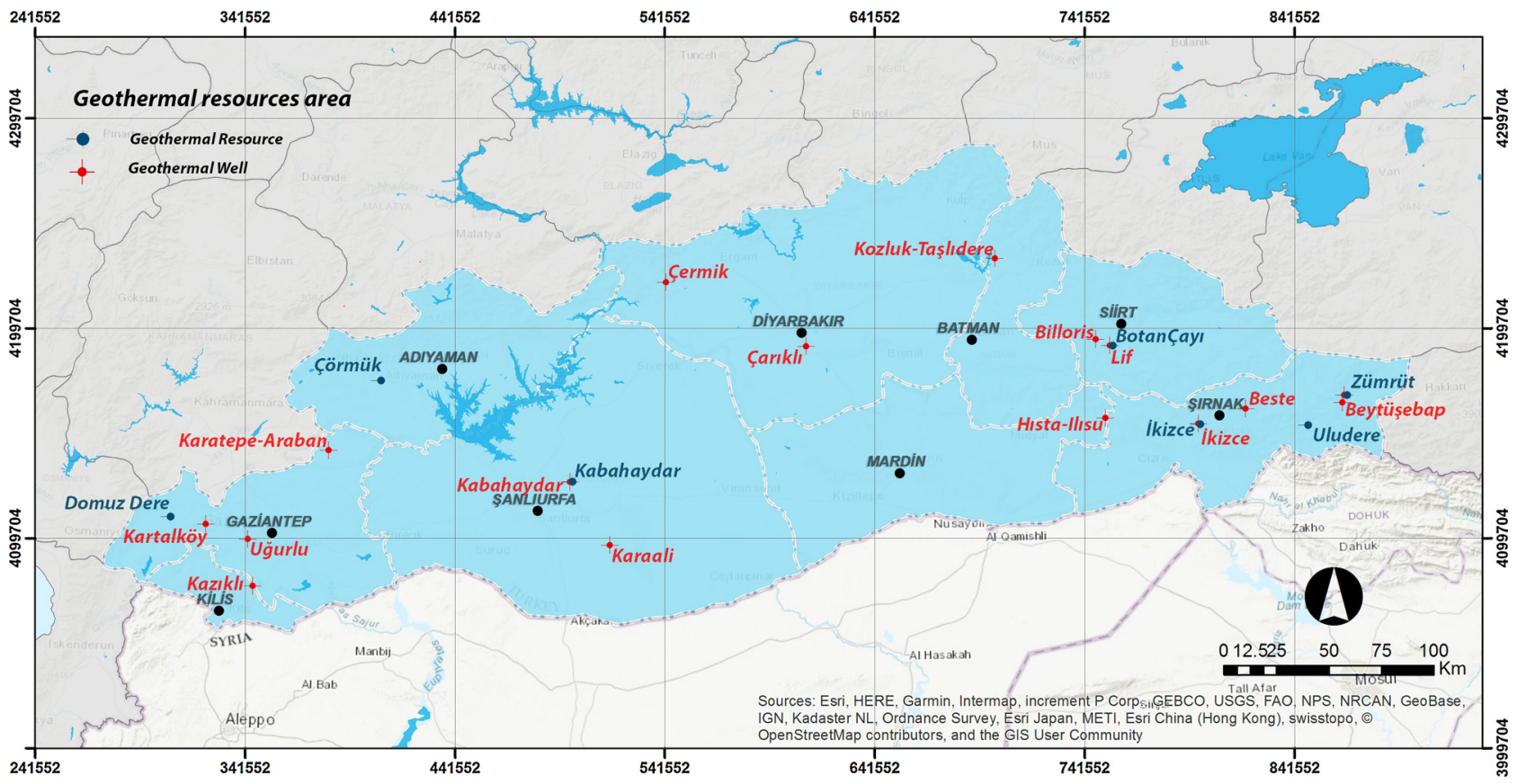

Fig. 7. Location of geothermal resources area (Baba et al., 2015b).

(meq/L). The distribution of water types of the geothermal fluid are shown in Fig. 8. The derivation of the statistical summaries for the hydrogeochemical data obtained was transferred to the Piper and Schoeller diagrams which are used quite frequently in hydrogeology (Fig. 9 and Fig. 10) for ease of imaging the ions collectively in a single diagram. According to the Piper classification, the class of the water is determined by the point where the ions intersecting the equilateral triangle and the point intersected by the equilateral quadrangle drawn on the two triangles are marked with $\% \mathrm{meq} / \mathrm{L}$ values for the ions. Triangular diagrams provide easy access to water facies types and quadrilateral diagrams facilitate water classification and comparison.

The Piper diyagram (Fig. 9) shows the dominant hydrochemical features of geothermal fluids in deep wells, hot springs and cold water in the study area. The geothermal fluids in deep wells (Kozlu-Taşlıdere) showed an enriched concentrations of $\mathrm{Na}^{+}$and $\mathrm{Cl}^{-}$ions, whereas thermal spring fluids showed an enriched concentration of $\mathrm{Ca}^{2+}$. The $\mathrm{Ca}^{2+}$ concentrations in thermal spring fluids ranged between 6.97 and $361.28 \mathrm{mg} / \mathrm{L}$. However, $\mathrm{Ca}^{2+}$ concentrations were generally low, ranged between 14.9 and $73.4 \mathrm{mg} / 1$ in cold water resources. Geothermal waters in deep wells is of the $\mathrm{Na}-\mathrm{Cl}$ type, whereas thermal spring fluids are mostly of the $\mathrm{Na}-\mathrm{HCO}_{3}, \mathrm{Ca}-\mathrm{Mg}-\mathrm{SO}_{4}, \mathrm{Ca}-\mathrm{Mg}-\mathrm{HCO}_{3}$, and $\mathrm{Ca}-\mathrm{SO}_{4}$ types. The cold waters are mainly dominated by $\mathrm{Ca}^{2+}$ and $\mathrm{Mg}^{2+}$ cations and $\mathrm{HCO}_{3}{ }^{-}$anions.

The Schoeller semi-logarithmic diagram is a diagram showing $\mathrm{Mg}$,

Table 1

EC $(\mu \mathrm{S} / \mathrm{cm})$ and $\mathrm{T}\left({ }^{\circ} \mathrm{C}\right)$ values for samples from the GAP region (Baba et al., 2015b).

\begin{tabular}{|c|c|c|c|c|c|c|}
\hline No & City & Location & $\begin{array}{l}\mathrm{EC} \\
(\mu \mathrm{S} / \mathrm{cm})\end{array}$ & $\mathrm{pH}$ & $\begin{array}{l}\mathrm{T} \\
\left({ }^{\mathrm{O}} \mathrm{C}\right)\end{array}$ & Type \\
\hline 1 & Gaziantep & Domuz Dere & 178 & 10.50 & 14.5 & Cold spring \\
\hline 2 & Gaziantep & Kartalköy & 1486 & 11.65 & 22.5 & Geothermal spring \\
\hline 3 & Gaziantep & Karatepe_Araban & 513 & 8.20 & 27.8 & Deep well \\
\hline 4 & Adiyaman & Çörmük & 510 & 7.62 & 15.9 & Cold spring \\
\hline 5 & Şanlıurfa & Kabahaydar & 1105 & 7.23 & 29.0 & Deep well \\
\hline 6 & Şanlıurfa & Kabahaydar & 589 & 7.38 & 23.8 & Deep well \\
\hline 7 & Şanlıurfa & Kabahaydar & 635 & 7.44 & 18.3 & Shallow well \\
\hline 8 & Şanlıurfa & Karaali & 792 & 7.41 & 41.0 & Deep well \\
\hline 9 & Diyarbakır & Çermik & 1370 & 7.27 & 51.0 & Geothermal spring \\
\hline 11 & Batman & Kozlu-Taşlıdere & 18,550 & 6.16 & 84.5 & Deep well \\
\hline 13 & Siirt & Billoris & 2310 & 6.40 & 33.1 & Geothermal spring \\
\hline 14 & Siirt & Botan Çayı & 577 & 7.02 & 15.2 & Cold spring \\
\hline 15 & Siirt & Lif Kaplıcası & 2390 & 6.50 & 33.7 & Geothermal spring \\
\hline 16 & Mardin & Ilısu (Germav) & 2220 & 6.55 & 56.6 & Geothermal spring \\
\hline 17 & Şırnak & Belkısana (Hısta) & 2260 & 6.77 & 62.2 & Geothermal spring \\
\hline 18 & Şırnak & Uludere-Beytülşebap & 320 & 8.13 & 8.6 & Cold spring \\
\hline 19 & Şırnak & Zümrüt Kaplıcası & 1739 & 6.75 & 44.0 & Geothermal spring \\
\hline 20 & Şırnak & Beytülşebap & 260 & 7.87 & 9.0 & Cold spring \\
\hline 21 & Şırnak & Kaniyagerm & 817 & 7.21 & 21.1 & Geothermal spring \\
\hline 22 & Şırnak & Nasfaran_İkizce & 1739 & 8.96 & 20.0 & Geothermal spring \\
\hline 23 & Şırnak & Nasfaran_İkizce & 1201 & 8.01 & 22.7 & Geothermal spring \\
\hline 24 & Şırnak & Beste & 1070 & 7.18 & 26.5 & Geothermal spring \\
\hline 25 & Şırnak & Beste & 1095 & 7.22 & 27.3 & Geothermal spring \\
\hline 26 & Kilis & Güvenli & 1530 & 7.32 & 35.0 & Deep well \\
\hline 27 & Gaziantep & Uğurlu Kaplıcası & 2116 & 7.01 & 34.8 & Deep well \\
\hline
\end{tabular}




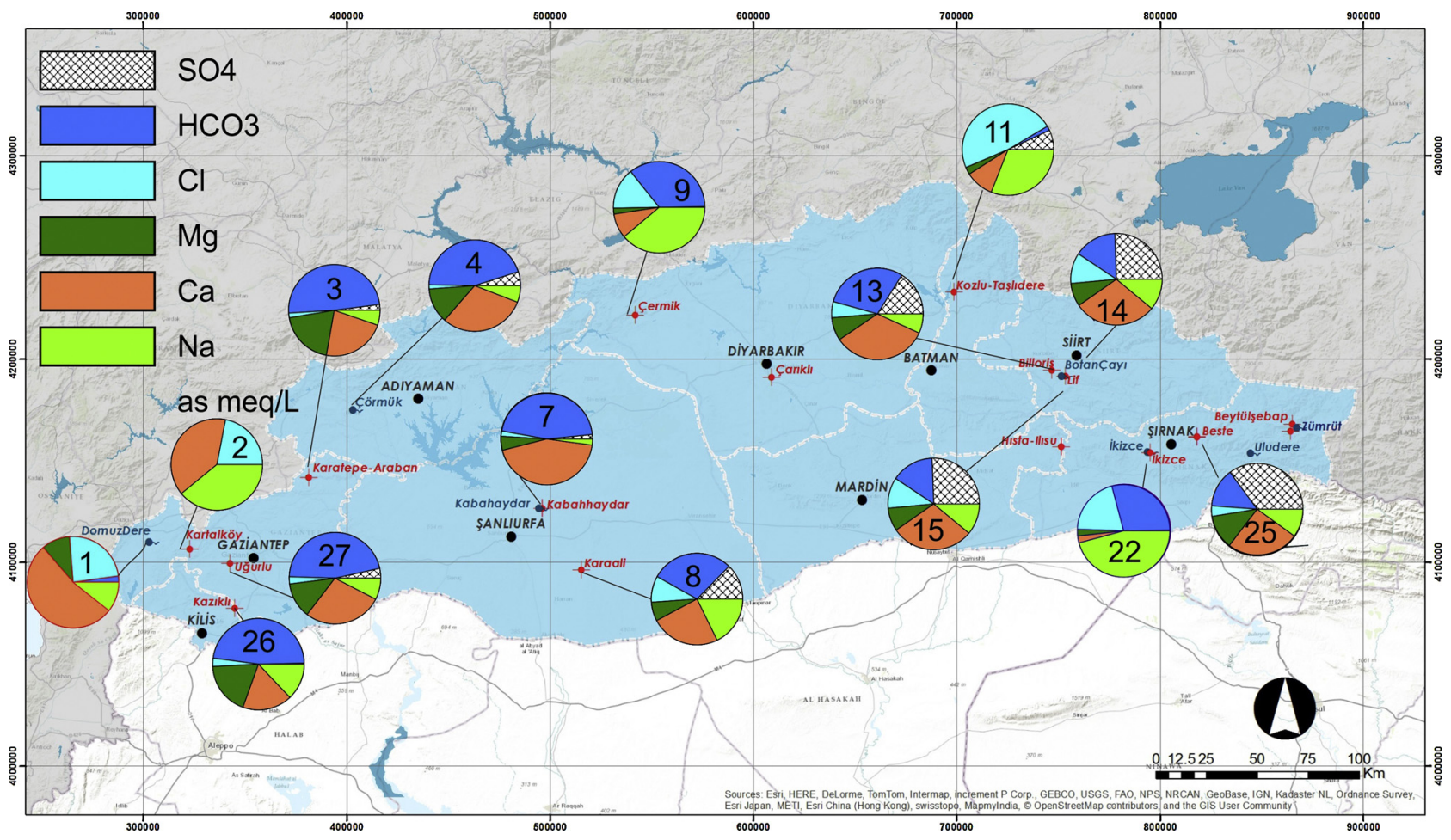

Fig. 8. Demonstration of the chemical properties of the geothermal resources in the GAP region (Baba et al., 2015b).

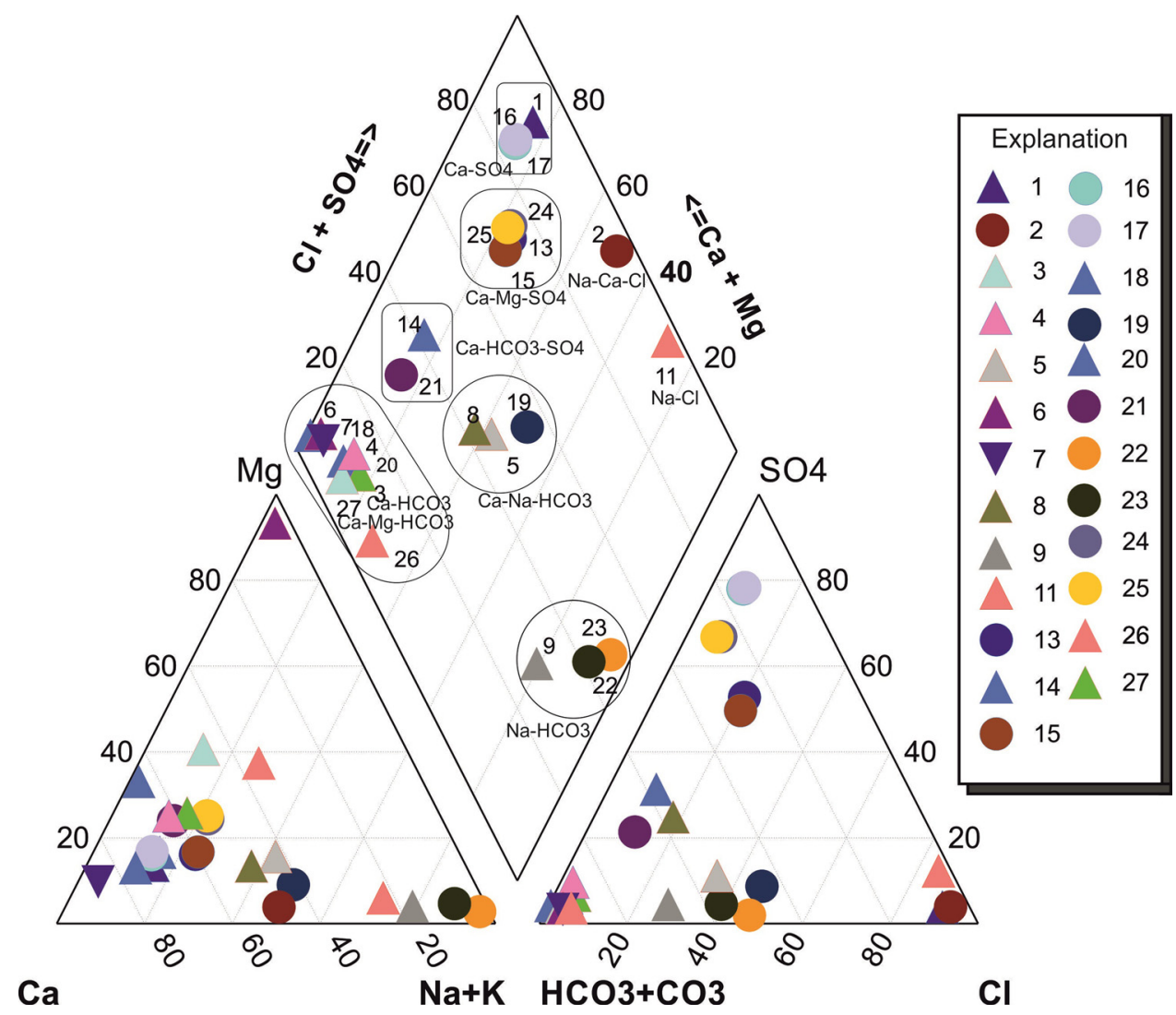

Fig. 9. Demonstration in the Piper diagram of the geothermal resources in the GAP Region.

$\mathrm{Ca}, \mathrm{Na}+\mathrm{K}, \mathrm{Cl}, \mathrm{SO}_{4}$ and $\mathrm{HCO}_{3}$ ion concentrations on the X-axis, respectively, where the constituent concentrations on the logarithmic scale $\mathrm{Y}$-axis are in meq/L. It was assessed whether the origins of the waters were similar by interpreting the lines formed by the element concentrations marked on this diagram. The semi-logarithmic Schoeller diagram (Fig. 10) shows that geothermal fluid samples have a different composition and it can be seen from the plots that their sodium $\left(\mathrm{Na}^{+}\right)$, calcium $\left(\mathrm{Ca}^{2+}\right)$, bicarbonate $\left(\mathrm{HCO}_{3}{ }^{-}\right)$and chloride $\left(\mathrm{Cl}^{-}\right)$ 


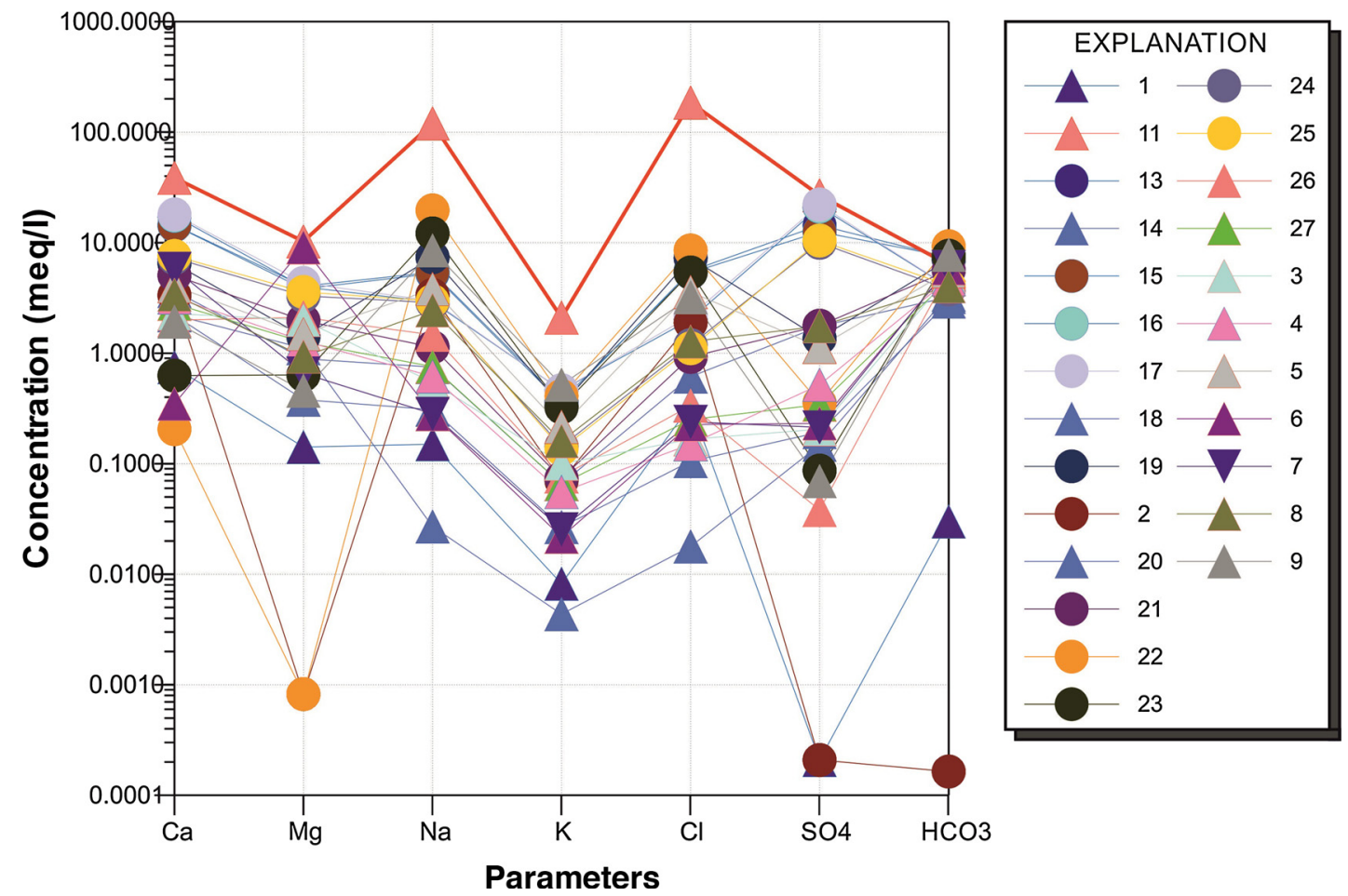

Fig. 10. Demonstration of geothermal resources in the Schoeller diagram of the GAP Region.

Table 2

Concentrations of major anions and cations in water resources (mg/l).

\begin{tabular}{|c|c|c|c|c|c|c|c|c|c|}
\hline No & $\mathrm{Na}^{+}$ & $\mathrm{K}^{+}$ & $\mathrm{Ca}^{2+}$ & $\mathrm{Mg}^{2+}$ & $\mathrm{Cl}^{-}$ & $\mathrm{SO}_{4}^{2-}$ & $\mathrm{HCO}_{3}{ }^{-}$ & $\mathrm{SiO}_{2}$ & Water type \\
\hline 1 & 3.45 & 0.32 & 14.92 & 1.72 & 12.01 & 0.01 & 1.83 & 1.54 & Ca-Na-Mg-Cl \\
\hline 2 & 77.15 & 2.73 & 66.92 & 0.01 & 66.91 & 0.01 & 0.01 & 0.16 & $\mathrm{Na}-\mathrm{Ca}-\mathrm{Cl}$ \\
\hline 3 & 12.49 & 3.91 & 45.56 & 24.23 & 5.91 & 9.86 & 303.78 & 15.28 & $\mathrm{Ca}-\mathrm{Mg}-\mathrm{HCO}_{3}$ \\
\hline 4 & 14.13 & 2.16 & 63.84 & 15.69 & 5.32 & 24.79 & 285.48 & 8.39 & $\mathrm{Ca}-\mathrm{Mg}-\mathrm{HCO}_{3}$ \\
\hline 5 & 87.45 & 8.42 & 80.97 & 18.1 & 126.83 & 54.74 & 336.72 & 11.32 & $\mathrm{Ca}-\mathrm{Na}-\mathrm{HCO}_{3}-\mathrm{Cl}$ \\
\hline 6 & 6.45 & 0.85 & 6.97 & 110.03 & 8.01 & 11.13 & 358.07 & 15.60 & $\mathrm{Mg}-\mathrm{HCO}_{3}$ \\
\hline 7 & 6.49 & 1 & 116.03 & 7.97 & 8.48 & 10.22 & 367.22 & 17.19 & $\mathrm{Ca}-\mathrm{HCO}_{3}$ \\
\hline 8 & 56.16 & 6.26 & 67.69 & 11.27 & 45.16 & 84.07 & 245.83 & 12.85 & $\mathrm{Ca}-\mathrm{Na}-\mathrm{HCO}_{3}-\mathrm{SO}_{4}$ \\
\hline 9 & 195.49 & 20.2 & 38.65 & 5.55 & 113.36 & 3.34 & 472.75 & 19.44 & $\mathrm{Na}-\mathrm{HCO}_{3}-\mathrm{Cl}$ \\
\hline 11 & 2756.06 & 81.89 & 773.56 & 124.67 & 6571.45 & 1287.24 & 384.3 & & $\mathrm{Na}-\mathrm{Cl}$ \\
\hline 13 & 120.47 & 13.79 & 286.92 & 46.39 & 196.8 & 689.23 & 446.52 & 12.89 & $\mathrm{Ca}-\mathrm{Na}-\mathrm{SO}_{4}-\mathrm{HCO}_{3}-\mathrm{Cl}$ \\
\hline 14 & 17.18 & 2.55 & 73.24 & 10.81 & 21.77 & 83.8 & 196.42 & 5.42 & $\mathrm{Ca}-\mathrm{HCO}_{3}-\mathrm{SO}_{4}$ \\
\hline 15 & 124.1 & 14.5 & 288.33 & 49.05 & 188.87 & 602.15 & 452.62 & 13.54 & $\mathrm{Ca}-\mathrm{Na}-\mathrm{SO}_{4}-\mathrm{HCO}_{3}-\mathrm{Cl}$ \\
\hline 16 & 67.06 & 18.03 & 350.31 & 48.26 & 71.67 & 1015.43 & 241.56 & $*$ & $\mathrm{Ca}-\mathrm{SO}_{4}$ \\
\hline 17 & 68.38 & 18.05 & 361.28 & 52.48 & 77.05 & 1062.15 & 242.17 & $*$ & $\mathrm{Ca}-\mathrm{SO}_{4}$ \\
\hline 18 & 0.62 & 0.17 & 44.3 & 13.47 & 0.63 & 7.09 & 205.57 & 2.075 & $\mathrm{Ca}-\mathrm{Mg}-\mathrm{HCO}_{3}$ \\
\hline 19 & 169.66 & 13.06 & 129.96 & 17.14 & 257.75 & 65.31 & 429.44 & 17.99 & $\mathrm{Na}-\mathrm{Ca}-\mathrm{Cl}-\mathrm{HCO}_{3}$ \\
\hline 20 & 7.08 & 1.04 & 44.15 & 4.61 & 3.73 & 9.26 & 178.73 & 2.60 & $\mathrm{Ca}-\mathrm{HCO}_{3}$ \\
\hline 21 & 26.02 & 2.87 & 101.34 & 23.98 & 32.83 & 85.07 & 342.82 & 8.92 & $\mathrm{Ca}-\mathrm{Mg}-\mathrm{HCO}_{3}-\mathrm{SO}_{4}$ \\
\hline 22 & 450.03 & 16.04 & 4.11 & 0.01 & 301.58 & 17.04 & 565.47 & 7.13 & $\mathrm{Na}-\mathrm{HCO}_{3}-\mathrm{Cl}$ \\
\hline 23 & 278.51 & 12.65 & 12.54 & 7.72 & 190.62 & 4.15 & 464.21 & 7.01 & $\mathrm{Na}-\mathrm{HCO}_{3}-\mathrm{Cl}$ \\
\hline 24 & 65.86 & 5.61 & 144.99 & 40.18 & 41.92 & 479.16 & 229.97 & 12.39 & $\mathrm{Ca}-\mathrm{Mg}-\mathrm{Na}-\mathrm{SO}_{4}-\mathrm{HCO}_{3}$ \\
\hline 25 & 68.12 & 5.31 & 151.87 & 43.45 & 39.3 & 501.11 & 249.49 & 12.53 & $\mathrm{Ca}-\mathrm{Mg}-\mathrm{SO}_{4}-\mathrm{HCO}_{3}$ \\
\hline 26 & 33.63 & 3 & 39.85 & 25.6 & 11.88 & 1.83 & 328.23 & 13.91 & $\mathrm{Mg}$-Ca-Na-HCO 3 \\
\hline 27 & 17.36 & 2.55 & 56.03 & 15.24 & 8.91 & 16.41 & 281.87 & 14.22 & $\mathrm{Ca}-\mathrm{Mg}-\mathrm{HCO}_{3}$ \\
\hline
\end{tabular}

* Not measured data.

concentrations are relatively higher than those of other chemical constituents (Table 2). $\mathrm{Na}^{+}$and $\mathrm{K}^{+}$concentrations are increased in the deep geothermal fluid by deep circulation. The hydrogeochemical studies show that the resulting waters reflect very different water types such as $\mathrm{Ca}-\mathrm{Mg}-\mathrm{SO}_{4}, \mathrm{Na}-\mathrm{HCO}_{3}, \mathrm{Na}-\mathrm{Cl}, \mathrm{Ca}-\mathrm{Mg}-\mathrm{HCO}_{3}, \mathrm{Ca}-\mathrm{HCO}_{3}$, and $\mathrm{Ca}-\mathrm{SO}_{4}$. The cold waters reflect the water types of $\mathrm{Ca}-\mathrm{Mg}-\mathrm{HCO}_{3}$ and $\mathrm{Ca}-\mathrm{HCO}_{3} \cdot \mathrm{Na}^{+}$is the major cation in the deep geothermal fluid of the study area with a concentration of $275,606 \mathrm{mg} / \mathrm{l}$. Concentrations of magnesium $\left(\mathrm{Mg}^{2+}\right)$ and calcium $\left(\mathrm{Ca}^{2+}\right)$ are increased $\left(\mathrm{Mg}^{2+}\right.$ values range from 0.01 to $124.67 \mathrm{mg} / 1$ and $\mathrm{Ca}^{2+}$ values range from 6.97 to $773.56 \mathrm{mg} / \mathrm{l})$ in deep geothermal fluid. The chloride $\left(\mathrm{Cl}^{-}\right)$concentration in the geothermal fluids ranges from 5.91 to $657,145 \mathrm{mg} / 1$. Two major anions, sulfate $\left(\mathrm{SO}_{4}{ }^{2-}\right)$ and bicarbonate $\left(\mathrm{HCO}_{3}{ }^{-}\right)$, have much lower concentrations than $\mathrm{Cl}^{-}$in the deep geothermal fluid (Fig. 8). The reservoir rocks of the geothermal systems in the study area are carbonated rocks belonging to the Mardin and Midyat groups. The water of these rocks is of $\mathrm{Ca}-\mathrm{Mg}-\mathrm{HCO}_{3}$ and $\mathrm{Ca}-\mathrm{HCO}_{3}$ types.

The Na-K-Mg ${ }^{1 / 2}$ ternary diagram was proposed by Giggenbach 
a)

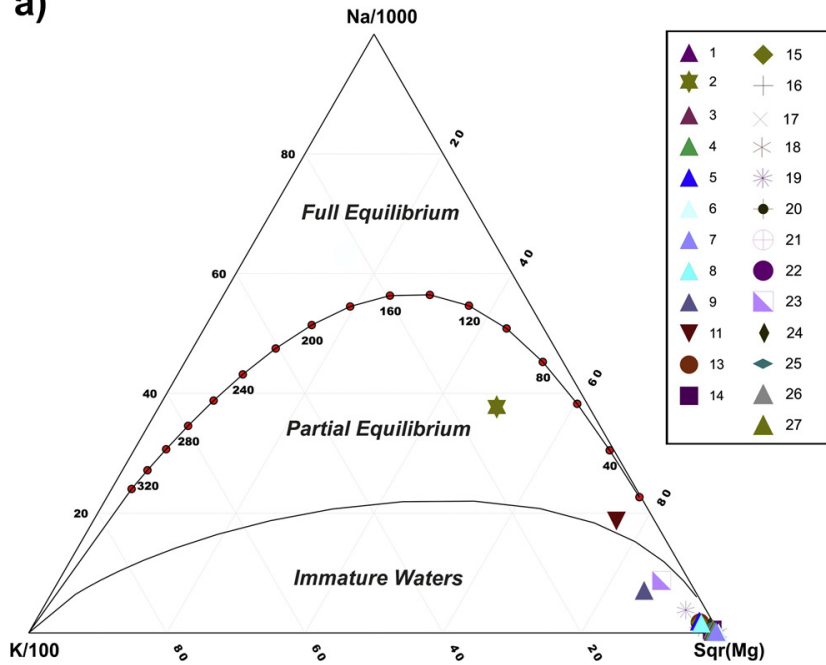

b)

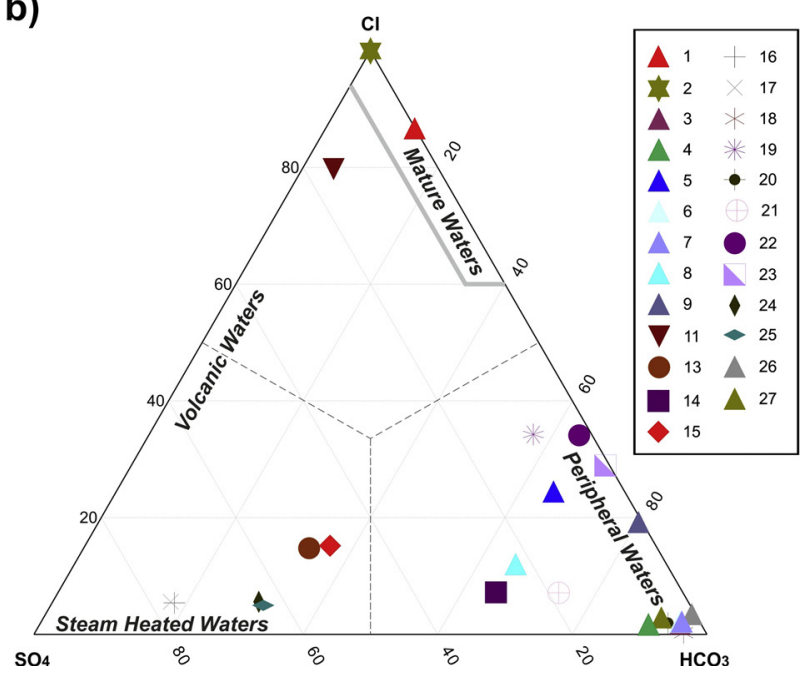

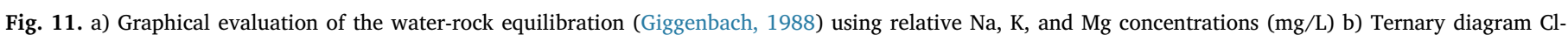
$\mathrm{SO}_{4}-\mathrm{HCO}_{3}$ to classified types of geothermal fluid.

(1988) as a method to make a clear distinction between the geothermal fluids that are suitable for the estimation of reservoir temperature by the application of solute geothermometers (Fig. 11a). According to this diagram, the thermal fluids in the GAP region plot in the immature zone except sample 1 (Kartalköy-Gaziantep) and sample 11 (Kozlu_TaşlıdereBatman).

A ternary plot of the major anions $\left(\mathrm{HCO}_{3}{ }^{-}-\mathrm{Cl}^{-}-\mathrm{SO}_{4}{ }^{2-}\right)$ show the different origins of geothermal fluids. The diagram indicates several types of thermal fluids such as immature waters, peripheral waters, volcanic, and steam heated waters. Fig. $11 \mathbf{b}$ shows that sample 1 plots in the mature waters region while samples 5, 8, 9, 14, 19, 22 and 23 plot in the peripheral water region and other samples $(13,15,16,17$, 24 and 25) plot in the steam heated water region. The $\mathrm{Cl}-\mathrm{SO}_{4}-\mathrm{HCO}_{3}$ classification plot indicates that most of the thermal fluids suggests that the waters in the geothermal springs are a mixture of deep water and shallow groundwater.

The concentrations of some minor elements are given in Table 3 . Aluminum (Al) is the third most common element in the earth's crust and is present in all water resources. The concentration of $\mathrm{Al}$ in the geothermal fluid ranges from $1 \mathrm{ppb}$ to $600 \mathrm{ppb}$. The extremely high values of $\mathrm{Al}$ are found in samples 11,16, 17 and 25. Sample 11 is taken from a deep abandoned oil production well which has been used for thermal tourism. These samples have been affected by oil veins. Samples 16 and 17 come from a shale which contains much higher concentrations of $\mathrm{Al}_{2} \mathrm{O}_{3}$, typically up to $15 \%$, due to the presence of clay minerals such as kaolinite. Arsenic (As) concentrations of geothermal fluid at sampling points $8,11,16,17,19,21,24$ and 25 ranged from 13.4 to $3000 \mathrm{ppb}$. The increase of As in geothermal fluid originates in water-rock interaction associated with arsenic-containing formations. High boron (B) concentrations of geothermal fluid cause some environmental problems for soil and water as they discharge because their salinities and boron concentrations are high and harmful for the agriculture in that area (Baba and Ármannsson (2006)). The extreme values for B were determined as $1000-3052 \mathrm{ppb}$ in five $(11,19,22,23)$ locations. The approximate safe limit for sensitive crops (for example, grape, pear, orange, and lemon) is $700 \mathrm{ppb} B$ in the soil saturation extract; 700 to $1500 \mathrm{ppb}$ is marginal, and more than $1500 \mathrm{ppm}$ appears to be unsafe (Camp, 1963). This is related to volcanic and sedimentary rocks but may also be controlled by the degassing of magma intrusives (Baba, 2015a; and 2015b). Iron (Fe) is the fourth most abundant element and second most abundant metal in the Earth's crust. Iron occurs naturally in volcanic rocks, associated soils, and alluvial sediments of volcanic origin. A high concentration of Fe can be seen in samples 13,
16 and 17. The concentrations of cadmium $(\mathrm{Cd})$, copper $(\mathrm{Cu})$, lead $(\mathrm{Pb})$, lithium (Li), zinc ( $\mathrm{Zn})$ and uranium (U) are also very high in samples 13,16 and 17 . Uranium (U) is a naturally occurring metal, which is widespread in nature. It is present in the ocean and certain types of soils and rocks, especially granite. The $\mathrm{U}, \mathrm{Cd}$, concentrations of these samples reaches $3000 \mathrm{ppb}$ and $700 \mathrm{ppb}$, respectively. The $\mathrm{Cu}$ values for these four samples reach $80 \mathrm{ppb}$. Chromium (Cr) is widely distributed in Earth's crust. The Cr values for the geothermal fluid in samples 13, 18 and 19 reach $300 \mathrm{ppb}$. Lead $(\mathrm{Pb})$ is widely distributed in sedimentary rocks. The $\mathrm{Pb}$ values of samples $11,13,16$ and 17 reach $4000 \mathrm{ppb}$. Lithium ( $\mathrm{Li}$ ) is the 27th most abundant element in nature. The extreme values for Li can be seen in samples 11, 13, 16, 17 and 19. The other geothermal fluids contain low concentrations of heavy metals.

\subsection{Isotope composition of water resources}

Stable isotopes are a very useful tool for determining the origin, transit time and direction of fluids in a groundwater system. Craig (1961) showed that the deuterium and oxygen-18 ratios in meteoric waters fit on a line known as the global meteoric water line (GMWL) symbolized by the formula in Eq. (1). However, $\delta^{18} \mathrm{O}$ and $\delta^{2} \mathrm{H}$ values at any locality are strongly dependent upon distance from the sea, continental effect, latitude and altitude (Nicholson, 1993a). In this manner, regional meteoric water lines (RMWL) and particularly local meteoric water lines (LMWL) are suitable references for understanding local groundwater isotopic distinctions with reference to local meteoric waters (Mazor, 2004). To explore whether the selected samples are modified or not, selected RMWLs (Gat, 1983; Eisenlohr, 1995) and LMWL (Sayün and Eyıpoğlu, 2005) are used (Eqs. (2) and (3)) and the study area data given in Table 4 are plotted (Fig. 12).

$\delta \mathrm{D}=8 \delta^{18} \mathrm{O}+10.00$ (Global Meteoric Water Line)

$\delta \mathrm{D}=8 \delta^{18} \mathrm{O}+22.00$ (Eastern Mediterranean Meteoric Water Line)

$\delta \mathrm{D}=8 \delta^{18} \mathrm{O}+16.00$ (Marmara Meteoric Water Line)

Fig. 12 indicates the relation of $\delta^{18} \mathrm{O}$ and $\delta^{2} \mathrm{H}$; deuterium $\left(\delta^{2} \mathrm{H}\right)$ values are in the range from -63.23 to $-33.66 \%$ and oxygen-18 $\left(\delta^{18} \mathrm{O}\right)$ values are in the range of -10.29 to $5.77 \%$. The graph results also show that the cold water and geothermal fluid classified as oxygen-enriched waters are of meteoric origin. The data is used to separate the waters into thermal and cold waters in the diagram and it is clustered between the RMWLs of the Eastern Mediterranean and Marmara. Isotope signatures for the site data do not have any trend indicating processes. The 
Table 3

Concentrations of minor elements in water resources.

\begin{tabular}{|c|c|c|c|c|c|c|c|c|c|c|c|c|c|}
\hline No & $\mathrm{Al}$ & As & B & $\mathrm{Ba}$ & $\mathrm{Bi}$ & $\mathrm{Br}$ & $\mathrm{Cd}$ & Co & $\mathrm{Cr}$ & $\mathrm{Cu}$ & $\mathrm{Fe}$ & $\mathrm{Hg}$ & $\mathrm{Li}$ \\
\hline Units & $\mathrm{ppb}$ & $\mathrm{ppb}$ & $\mathrm{ppb}$ & $\mathrm{ppb}$ & $\mathrm{ppb}$ & $\mathrm{ppb}$ & $\mathrm{ppb}$ & $\mathrm{ppb}$ & $\mathrm{ppb}$ & $\mathrm{ppb}$ & $\mathrm{ppb}$ & $\mathrm{ppb}$ & $\mathrm{ppb}$ \\
\hline 1 & 30 & $<0.5$ & 115 & 3.61 & $<0.05$ & 62 & $<0.05$ & 0.35 & 1.3 & 0.6 & 32 & 0.2 & 2.5 \\
\hline 2 & 3 & 1.1 & 101 & 3.19 & $<0.05$ & 328 & $<0.05$ & 0.02 & 0.8 & 0.2 & $<10$ & 0.3 & 7.4 \\
\hline 3 & 1 & $<0.5$ & 78 & 162.56 & $<0.05$ & 31 & $<0.05$ & $<0.02$ & 2.9 & 0.4 & $<10$ & $<0.1$ & 10.5 \\
\hline 4 & 2 & 0.7 & 109 & 265.19 & $<0.05$ & 23 & $<0.05$ & $<0.02$ & 2.5 & 1.2 & $<10$ & $<0.1$ & 8.7 \\
\hline 5 & $<1$ & 1.8 & 454 & 133.84 & $<0.05$ & 710 & $<0.05$ & 0.04 & 5.5 & 0.8 & 79 & 0.1 & 71 \\
\hline 6 & 3 & 1.7 & 53 & 505.3 & $<0.05$ & 78 & 0.41 & 1.25 & 5.7 & 1.5 & $<10$ & $<0.1$ & 7.5 \\
\hline 7 & $<1$ & 1.7 & 48 & 571.52 & $<0.05$ & 84 & $<0.05$ & $<0.02$ & 5.7 & 0.6 & $<10$ & $<0.1$ & 7.9 \\
\hline 8 & 1 & 44 & 211 & 89.2 & $<0.05$ & 265 & 0.18 & 7.77 & 0.6 & 3.1 & 39 & $<0.1$ & 33.8 \\
\hline 9 & $<1$ & 1.7 & 723 & 401 & $<0.05$ & 596 & $<0.05$ & $<0.02$ & 0.5 & 1.1 & $<10$ & $<0.1$ & 453 \\
\hline 11 & $<600$ & $<3000$ & 3052 & 204 & $<3000$ & & $<700$ & $<300$ & $<300$ & $<80$ & $<10,000$ & & $<1000$ \\
\hline 13 & 6 & 24.2 & 778 & 28.77 & $<0.05$ & 974 & $<0.05$ & $<0.02$ & 8.3 & 3.9 & $<10$ & $<0.1$ & 328.4 \\
\hline 14 & 90 & 3.4 & 115 & 29.74 & $<0.05$ & 120 & $<0.05$ & 0.18 & 3.3 & 1 & 105 & $<0.1$ & 37.2 \\
\hline 15 & 2 & 27.8 & 860 & 28.17 & $<0.05$ & 1040 & $<0.05$ & $<0.02$ & 9.5 & 3.8 & $<10$ & $<0.1$ & 360 \\
\hline 16 & $<600$ & $<3000$ & $<400$ & $<80$ & $<3000$ & $*$ & $<700$ & $<300$ & $<300$ & $<80$ & $<10,000$ & $*$ & $<1000$ \\
\hline 17 & $<600$ & $<\mathbf{3 0 0 0}$ & $<400$ & $<80$ & $<3000$ & * & $<700$ & $<300$ & $<300$ & $<80$ & $<10,000$ & $*$ & $<1000$ \\
\hline 18 & 10 & 0.6 & 11 & 15.95 & $<0.05$ & 12 & $<0.05$ & $<0.02$ & 2 & 0.4 & $<10$ & $<0.1$ & 0.5 \\
\hline 19 & 4 & 33.1 & 1000 & 208.42 & $<0.05$ & 454 & $<0.05$ & 0.06 & 7.4 & 0.7 & $<10$ & $<0.1$ & 358.7 \\
\hline 20 & 91 & $<0.5$ & 17 & 209.59 & $<0.05$ & 7 & $<0.05$ & 2.29 & 2.7 & 0.9 & 46 & $<0.1$ & 0.3 \\
\hline 21 & 20 & 35.2 & 171 & 83.2 & $<0.05$ & 99 & $<0.05$ & $<0.02$ & 3.2 & 1 & $<10$ & $<0.1$ & 55.6 \\
\hline 22 & 12 & 2.5 & 3364 & 147.96 & $<0.05$ & 1174 & $<0.05$ & 0.02 & 16.5 & 0.7 & 19 & 0.5 & 52.7 \\
\hline 23 & 15 & 1.5 & 1677 & 781.76 & $<0.05$ & 734 & $<0.05$ & 0.04 & 10.6 & 0.6 & 26 & 0.3 & 36.7 \\
\hline 24 & 6 & 15.3 & 432 & 22.67 & $<0.05$ & 156 & $<0.05$ & 0.14 & 4.5 & 1.9 & $<10$ & 0.2 & 62.5 \\
\hline 25 & 431 & 13.4 & 423 & 22.92 & $<0.05$ & 156 & $<0.05$ & 0.03 & 3.7 & 2 & 42 & 0.3 & 70.8 \\
\hline 26 & 1 & $<0.5$ & 59 & 881.98 & $<0.05$ & 55 & $<0.05$ & $<0.02$ & 10.6 & 0.4 & 16 & $<0.1$ & 18.6 \\
\hline 27 & 1 & 0.9 & 42 & 178.46 & $<0.05$ & 44 & $<0.05$ & 0.08 & 9.3 & 1.4 & $<10$ & $<0.1$ & 3.7 \\
\hline No & $\mathrm{Mn}$ & Mo & & $\mathrm{Pb}$ & $\mathrm{Rb}$ & S & $\mathrm{Sb}$ & $\mathrm{Se}$ & $\mathrm{S}$ & & $\mathrm{U}$ & V & $\mathrm{Zn}$ \\
\hline Units & $\mathrm{ppb}$ & $\mathrm{ppb}$ & & $\mathrm{ppb}$ & $\mathrm{ppb}$ & ppm & $\mathrm{ppb}$ & $\mathrm{ppb}$ & & $\mathrm{pb}$ & $\mathrm{ppb}$ & $\mathrm{ppb}$ & $\mathrm{ppb}$ \\
\hline 1 & 14.73 & $<0.1$ & & $<0.1$ & 0.54 & $<1$ & $<0.05$ & $<0.5$ & & 3.12 & $<0.02$ & 0.8 & 1.6 \\
\hline 2 & $<0.05$ & 0.2 & & $<0.1$ & 1.19 & 1 & $<0.05$ & 0.5 & & 9.71 & $<0.02$ & 0.9 & $<0.5$ \\
\hline 3 & 27.95 & 1.4 & & $<0.1$ & 6.54 & 5 & $<0.05$ & $<0.5$ & & 591.25 & $<0.02$ & $<0.2$ & 1 \\
\hline 4 & 2.15 & 1.6 & & $<0.1$ & 1.23 & 11 & 0.06 & 0.6 & & 18.25 & 0.35 & 2.1 & 1.9 \\
\hline 5 & 24.27 & 0.5 & & $<0.1$ & 9.09 & 22 & $<0.05$ & 1.2 & & 228.21 & $<0.02$ & 1.1 & 0.7 \\
\hline 6 & 32.66 & 2 & & $<0.1$ & 0.84 & 7 & 0.13 & 1.3 & & 13.59 & 0.88 & 9.5 & 17.5 \\
\hline 7 & 4.49 & 0.3 & & $<0.1$ & 0.97 & 6 & $<0.05$ & 1 & & 53.27 & 0.96 & 11.3 & 7.5 \\
\hline 8 & 3.15 & 146.4 & & $<0.1$ & 8.04 & 30 & 5.17 & 153.1 & & 196.35 & 58.24 & 2405.8 & 25.2 \\
\hline 9 & 2.91 & $<0.1$ & & $<0.1$ & 34.39 & 32 & $<0.05$ & 2 & & 232.3 & 0.07 & 0.6 & 0.6 \\
\hline 11 & $<50$ & $<300$ & & $<4000$ & & 406 & $<2000$ & " & & 6,908 & $<3000$ & $<200$ & $<300$ \\
\hline 13 & 14.57 & 2.4 & & $<0.1$ & 33.87 & 207 & $<0.05$ & 1.9 & & 1727.87 & 0.65 & 1.2 & 3.4 \\
\hline 14 & 16.47 & 0.4 & & 0.1 & 5 & 29 & $<0.05$ & 0.5 & & 99.09 & 0.34 & 1.8 & 2 \\
\hline 15 & 13.78 & 2.5 & & $<0.1$ & 36.39 & 206 & $<0.05$ & 2 & & 7555.44 & 0.66 & 1.2 & 2.8 \\
\hline 16 & $<50$ & $<300$ & & $<4000$ & $*$ & 515 & $<2000$ & * & & 442 & $<3000$ & $<200$ & $<300$ \\
\hline 17 & $<50$ & $<300$ & & $<4000$ & * & 860 & $<2000$ & $*$ & & 3144 & $<3000$ & $<200$ & $<300$ \\
\hline 18 & 9.75 & 0.2 & & 0.3 & 0.35 & 4 & $<0.05$ & $<0.5$ & & 91.45 & 0.34 & 0.5 & 3.4 \\
\hline 19 & 21.64 & 0.9 & & $<0.1$ & 33.74 & 39 & $<0.05$ & 0.8 & & 346.19 & 0.36 & 1.2 & 0.6 \\
\hline 20 & 81.22 & $<0.1$ & & $<0.1$ & 0.84 & 3 & $<0.05$ & $<0.5$ & & 86.5 & $<0.02$ & 0.5 & 3.1 \\
\hline 21 & 1.95 & 0.5 & & $<0.1$ & 4.99 & 33 & $<0.05$ & $<0.5$ & & 309.37 & 0.48 & 0.7 & 1.6 \\
\hline 22 & 6.69 & 0.5 & & $<0.1$ & 27.98 & 16 & $<0.05$ & 2.9 & & 294.49 & $<0.02$ & 4.9 & 1 \\
\hline 23 & 6.36 & $<0.1$ & & $<0.1$ & 14.07 & 13 & $<0.05$ & 1.7 & & 2947.69 & $<0.02$ & 3.2 & 0.8 \\
\hline 24 & 66.17 & $<0.1$ & & $<0.1$ & 14.2 & 151 & $<0.05$ & 0.9 & & 210.93 & 0.04 & 2.5 & 2.7 \\
\hline 25 & 78.62 & $<0.1$ & & $<0.1$ & 14.04 & 157 & $<0.05$ & 0.7 & & 454.9 & 0.08 & 3.9 & 3.9 \\
\hline 26 & 3.82 & 0.4 & & $<0.1$ & 5.05 & $<1$ & $<0.05$ & $<0.5$ & & 106.32 & $<0.02$ & $<0.2$ & 0.9 \\
\hline 27 & 2.92 & 3.2 & & $<0.1$ & 2.45 & 7 & 0.15 & 3.3 & & 1895.73 & 0.4 & 0.4 & 169.7 \\
\hline
\end{tabular}

* Not measured data.

relation diagram of deuterium $\left(\delta^{2} \mathrm{H}\right)$ and oxygen-18 $\left(\delta^{18} \mathrm{O}\right)$ shows that the source of the geothermal fluid is meteoric water.

The activity of tritium $\left(\delta^{3} \mathrm{H}\right.$, half-life 12.43 years) in thermal waters makes it a useful tracer for underground residence times. The activity of $\delta^{3} \mathrm{H}$ shows groundwater circulation time spent from recharge to discharge and it can be simply stated as the lower the $\delta^{3} \mathrm{H}$ amount in groundwater, the longer its residence or route. The results show that $\delta^{3} \mathrm{H}$ values less than 6 tritiums units indicate mixing of pre and post1952 recharges, while the values more than 6 tritium are an indication of a post-1952 recharge. $\delta^{3} \mathrm{H}$ values in geothermal fluid and cold water resources are in the range from 0 to $5.99 \%$ and 4.35 to $6.49 \%$, respectively. The tritium value from Kaniyagerm (Ş1rnak), where the water is emerging in the stream, is highest. This geothermal spring sample has been affected by cold water. The results of tritium $\left(\delta^{3} \mathrm{H}\right)$ isotope analysis of geothermal fluid of the study area shows that the geothermal fluids are older than 60 years. Tritium $\left(\delta^{3} \mathrm{H}\right)$ isotope values for cold water resources are higher than those for geothermal fluids (Fig. 12a). The high tritium and low deuterium values plotted in Fig. 12b represents a rapid circulation in the shallow groundwater system while the higher $\delta^{2} \mathrm{H}$ and lower $\delta^{3} \mathrm{H}$ values for the geothermal brine imply a longer and deeper circulation of the groundwater.

\section{Oil wells}

The GAP region is one of the important areas for oil production in Turkey. The TPAO has drilled a number of wells for oil. However, some of them have been abandoned. Many abandoned oil wells issue a geothermal fluid. The depths of these wells are in the range from $1270 \mathrm{~m}$ to 
Table 4

Ratios of $\delta^{18} \mathrm{O}, \delta^{2} \mathrm{H}$ and $\delta^{3} \mathrm{H}$ in water resources.

\begin{tabular}{llll}
\hline Sample Number & \multicolumn{1}{l}{$\delta^{2} \mathrm{H}$} & $\delta^{18} \mathrm{O}$ & $\delta^{3} \mathrm{H}$ \\
\hline $\mathbf{1}$ & -48.19 & -6.79 & $\mathrm{nd}$ \\
$\mathbf{2}$ & -45.42 & -7.87 & 0.00 \\
$\mathbf{3}$ & -57.84 & -9.41 & 0.00 \\
$\mathbf{4}$ & -42.03 & 7.38 & 4.35 \\
$\mathbf{6}$ & -33.66 & -5.77 & 5.55 \\
$\mathbf{8}$ & -47.89 & -7.36 & 1.79 \\
$\mathbf{9}$ & -63.23 & -10.29 & 0.00 \\
$\mathbf{1 1}$ & -59.81 & -9.52 & 0.00 \\
$\mathbf{1 3}$ & -48.19 & -7.87 & 2.48 \\
$\mathbf{1 4}$ & -59.63 & -9.68 & 6.49 \\
$\mathbf{1 5}$ & -50.65 & -7.42 & 1.40 \\
$\mathbf{1 6}$ & -57.70 & -8.91 & 0.21 \\
$\mathbf{1 7}$ & -58.03 & -9.05 & 0.00 \\
$\mathbf{1 8}$ & -53.02 & -9.01 & 5.83 \\
$\mathbf{1 9}$ & -57.89 & -9.53 & 3.40 \\
$\mathbf{2 1}$ & -56.87 & -9.43 & 5.99 \\
\end{tabular}

$3220 \mathrm{~m}$ and fluid temperatures of these wells range from 51 to $109^{\circ} \mathrm{C}$ in the Batman Region where one of the abandoned wells has been used for greenhouses and thermal tourism. The well head temperature of this well is $84.5^{\circ} \mathrm{C}$ and the flow rate is $16 \mathrm{~L} / \mathrm{sec}$. Also, the TPAO has drilled a number of wells for oil production in the Diyarbakır and Şırnak Regions. The depths of wells in Diyarbakır are between 1450 and $3960 \mathrm{~m}$ and the wellhead temperatures are in the range from 41 to $107^{\circ} \mathrm{C}$. The depths of the Şırnak wells are between 1520 and $3830 \mathrm{~m}$ and the temperature range has increased to 56 to $137^{\circ} \mathrm{C}$, respectively.

\section{Results and discussion}

The GAP region and its boundaries play an important role in plate tectonics, geological processes, and economic geology being a petroleum province throughout geological time. Anatolia has been experiencing crustal shortening and thickening as a result of a northward motion of the Arabian plate and the resulting deformation can be seen in the GAP region and the surrounding area. Folds and anticlines (that corresponds to the Bitlis-Zagros Fold and Thrust Belt) contain several important oil-fields in the Cretaceous Mardin Group limestones and show that structural traps are also very important for hydrothermal systems.

This study is the only research on geothermal potential and its properties in the southern part of Anatolia. Many wells have been drilled for oil production. Some of them abound with geothermal fluid. Significant hydrothermal alterations that could indicate geothermal activity is not observed in this region. Regional geodynamic evolution,
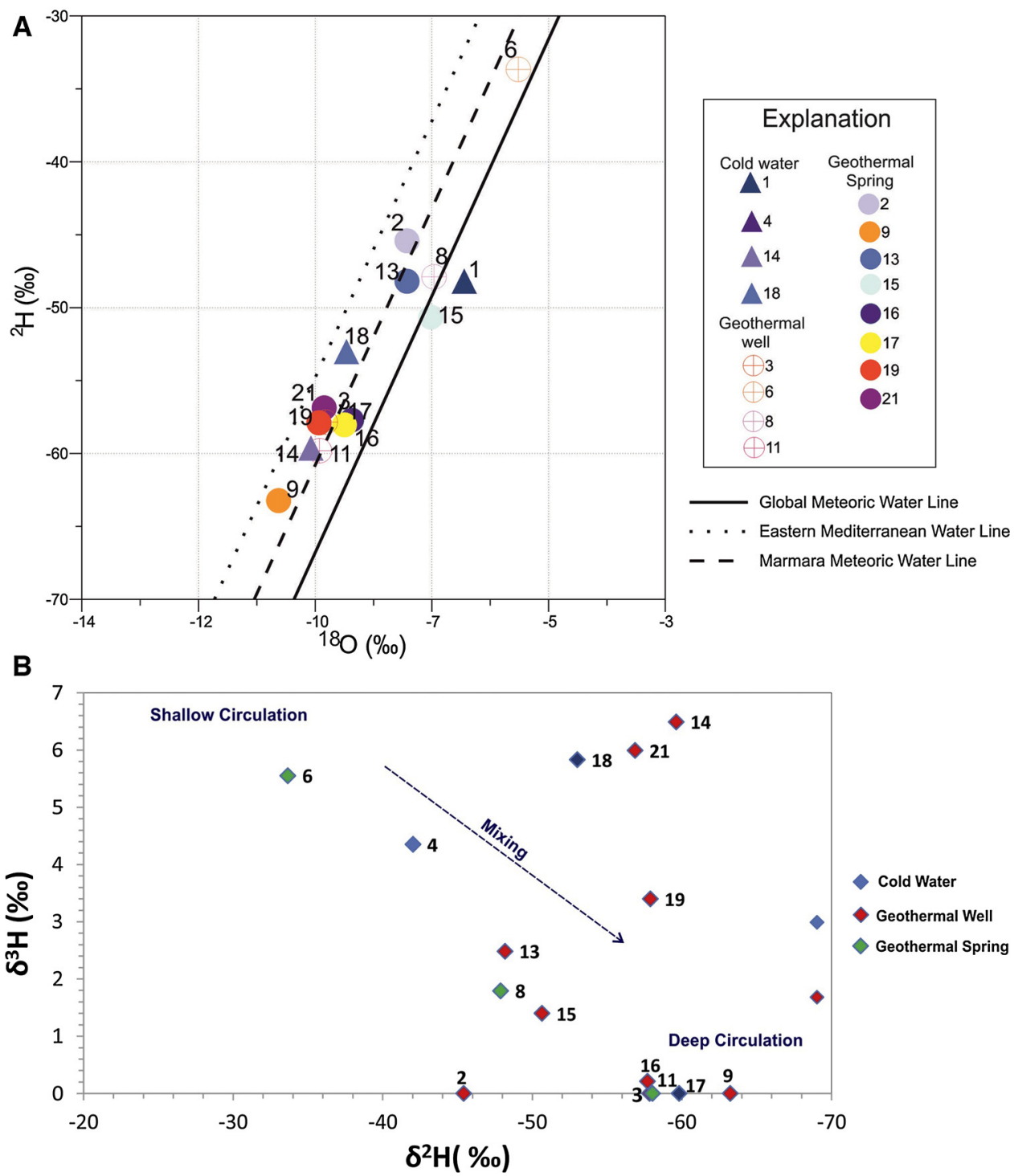

Fig. 12. a) $\delta^{18} \mathrm{O}(\%)$ versus $\delta^{2} \mathrm{H}(\% 0)$ diagram of the study area b) $\delta^{3} \mathrm{H}(\% 0)$ versus $\delta^{2} \mathrm{H}(\% 0)$ diagram. 


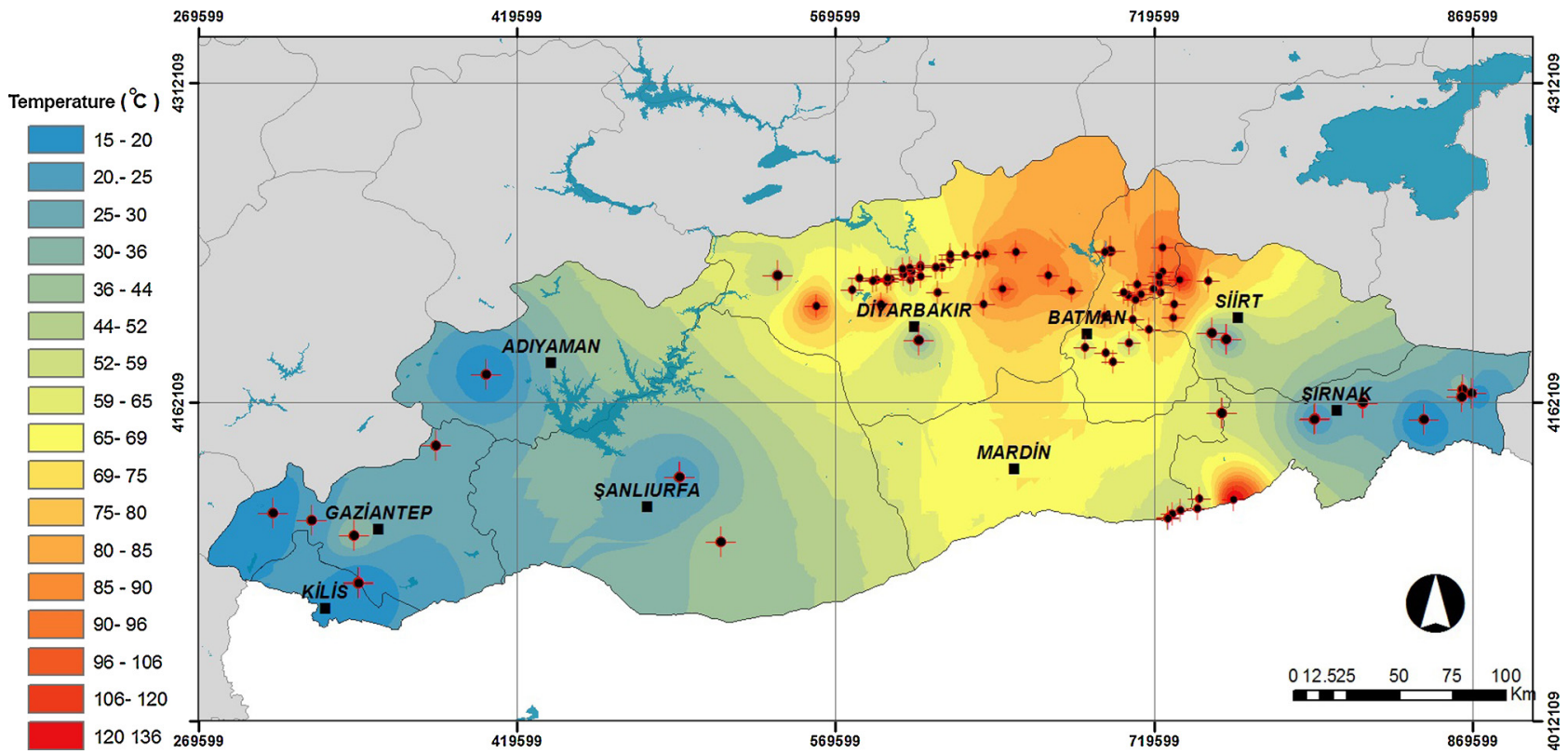

Fig. 13. Distrubition of all surface temperature of geothermal fluid data in GAP region.

contemporary tectonic and lithostratigraphic structures explain that geological environments of the region are suitable for the development of geothermal systems. Discontinuity features such as fault systems, which are structural elements of the current tectonic regime that has developed in the region, are permeable zones that facilitate fluid motion that takes place as meteoric water leaks into the ground and is heared.

The Cretaceous Mardin Group and the Eocene Midyat Group limestones constitute the main reservoirs of the geothermal systems in the region due to their prevalence and thicknesses in both regions in the Southeastern Anatolia Region. The Germav shales belonging to the Cretaceous Sirnak Group, Miocene Lice, and Şelmo formations are the main cap rocks of the geothermal systems. A basaltic volcano is the heat source for the geothermal resources. The compressive tectonic regime is present on a continental scale in the region. N-S directional cracks are the main structural elements which facilitate fluid transports to the surface. Lava and thermal fluid have been observed to use the same or similar fault systems in this region. Based on observation, it can be said that the parameters may be related to each other. Because of geological properties of the region, geothermal water is of very different types such as Ca-Mg-SO $\mathrm{S}_{4}, \mathrm{Na}-\mathrm{HCO}_{3}, \mathrm{Na}-\mathrm{Cl}, \mathrm{Ca}-\mathrm{Mg}-\mathrm{HCO}_{3}, \mathrm{Ca}-\mathrm{HCO}_{3}$ and $\mathrm{Ca}-\mathrm{SO}_{4}$ in the study area. Generally, the anion and cation concentrations in the cold waters are lower than in the thermal waters. Moreover, electrical conductivity and temperature values for the cold waters are much lower than for the thermal waters. Cold waters are of the water types $\mathrm{Ca}-\mathrm{Mg}-\mathrm{HCO}_{3}$ and $\mathrm{Ca}-\mathrm{HCO}_{3} . \mathrm{Na}^{+}$and $\mathrm{K}^{+}$concentrations are increased in the deep geothermal fluid by deep circulation. The water types is transformed from a dominant $\mathrm{Ca}^{2+}$ and $\mathrm{HCO}_{3}{ }^{-}$water to a dominant $\mathrm{Na}^{+}$and $\mathrm{Cl}^{-}$ions as stated in Eq. (4).

$\mathrm{Ca}-\mathrm{HCO}_{3} \rightarrow \mathrm{Ca}-\mathrm{Na}-\mathrm{HCO}_{3} \rightarrow \mathrm{Na}-\mathrm{HCO}_{3}-\mathrm{Cl}$

It is clear that geothermal fluids have relatively deeper circulation routes than cold water on the assumption that they are fluids ascending due to water-rock interaction in the GAP region. Geothermal fluid in this region is of Na-Cl type (such as Kozlu-Taşlidere (Batman); Kartalköy (Gaziantep)); Ca-SO ${ }_{4}$ type (such as Ilısu (Mardin) and Belkısana (Şırnak)) and $\mathrm{Na}-\mathrm{HCO}_{3}$ type (such as Karaali (Urfa), Nasfaran-İkizce (Şırnak)). The chemical composition of the geothermal fluids is affected by water temperature. For example, cold water found in the Beytülşebap geothermal field and vicinity is of $\mathrm{Ca}-\mathrm{HCO}_{3}$ type, the low-temperature thermal spring water is of $\mathrm{Na}-\mathrm{Ca}-\mathrm{Cl}$ type, which emerges from the mixture of cold and hot water derived from the shallow reservoir. The same situation has been seen in the Kabahaydar geothermal field (Şanllurfa) where cold groundwater is of the $\mathrm{Ca}-\mathrm{HCO}_{3}$ type, the low-temperature thermal spring water is of the Ca$\mathrm{Na}-\mathrm{HCO}_{3}$ type which is derived from the shallow reservoir. However, Kozlu geothermal water (Batman) is of $\mathrm{Na}-\mathrm{Cl}$ type. This type of water is a sign that the water comes from deep reservoirs. The Ilisu geothermal fluid is influenced by the dissolution of sulfate minerals (mainly gypsum and anhydrite) contained in the Eocene sediments.

The concentrations of some minor elements such as arsenic, boron, and lithium are high in the GAP geothermal fluid. Arsenic (As) concentrations in the geothermal fluid reach up to $3000 \mathrm{ppb}$. The increase of As concentrations in geothermal fluid originates in water-rock interaction associated with arsenic-containing formations. In addition, the extreme values of B are observed as $3364 \mathrm{ppb}$ in Nasfaran-íkizce (Şırnak). This is related to volcanic and sedimentary rocks but may also be controlled by the degassing of magma intrusives. The value of Li has reached up to $453 \mathrm{ppb}$ at the Zümrüt geothermal site (Şırnak). Li is usually widely distributed in nature, with trace amounts occurring in most rocks and soils and in several geothermal fluids.

Isotope analysis (such as $\delta^{18} \mathrm{O}$ and $\delta^{2} \mathrm{H}$ ) results show that the cold water and geothermal fluid classified as oxygen-enriched waters are of meteoric origin. The tritium $\left(\delta^{3} \mathrm{H}\right)$ isotope analysis of the geothermal fluids indicates that geothermal fluids are older than 60 years. Tritium $\left(\delta^{3} \mathrm{H}\right)$ isotope values for cold water resources are higher than those for the geothermal fluids.

A number of geothermal springs such as the Zümrüt Kaplicası (Şırnak), Belkısana (Mardin) reach the surface in different parts of the Southeastern Anatolia Region. The surface temperatures of these springs are in the range from 20 to $63^{\circ} \mathrm{C}$. In addition, some shallow wells, whose depths are in the range from 183 to $1005 \mathrm{~m}$, were drilled in the Karaali (Şanlıurfa) geothermal field where the well head temperature ranges from 38 to $58^{\circ} \mathrm{C}$. From these sources, Karaali and Kabahaydar (Şanlıurfa), Germav-Ilısu (Mardin), Hısta and Ilıcak (Şırnak), Çermik (Diyarbakır), Billoris (Siirt), Taşlıdere (Batman) and Durantaş have been utilized for thermal tourism and greenhouses. These practices are very primitive. There is also a large number of wells that have been drilled for oil production in this region. The abandoned oil wells have geothermal fluid but this fluid has not been used. The Adıyaman, Batman, Diyarbakır, and Şırnak provinces have reservoir temperatures reaching $137^{\circ} \mathrm{C}$ in the wells drilled by the TPAO at depths 


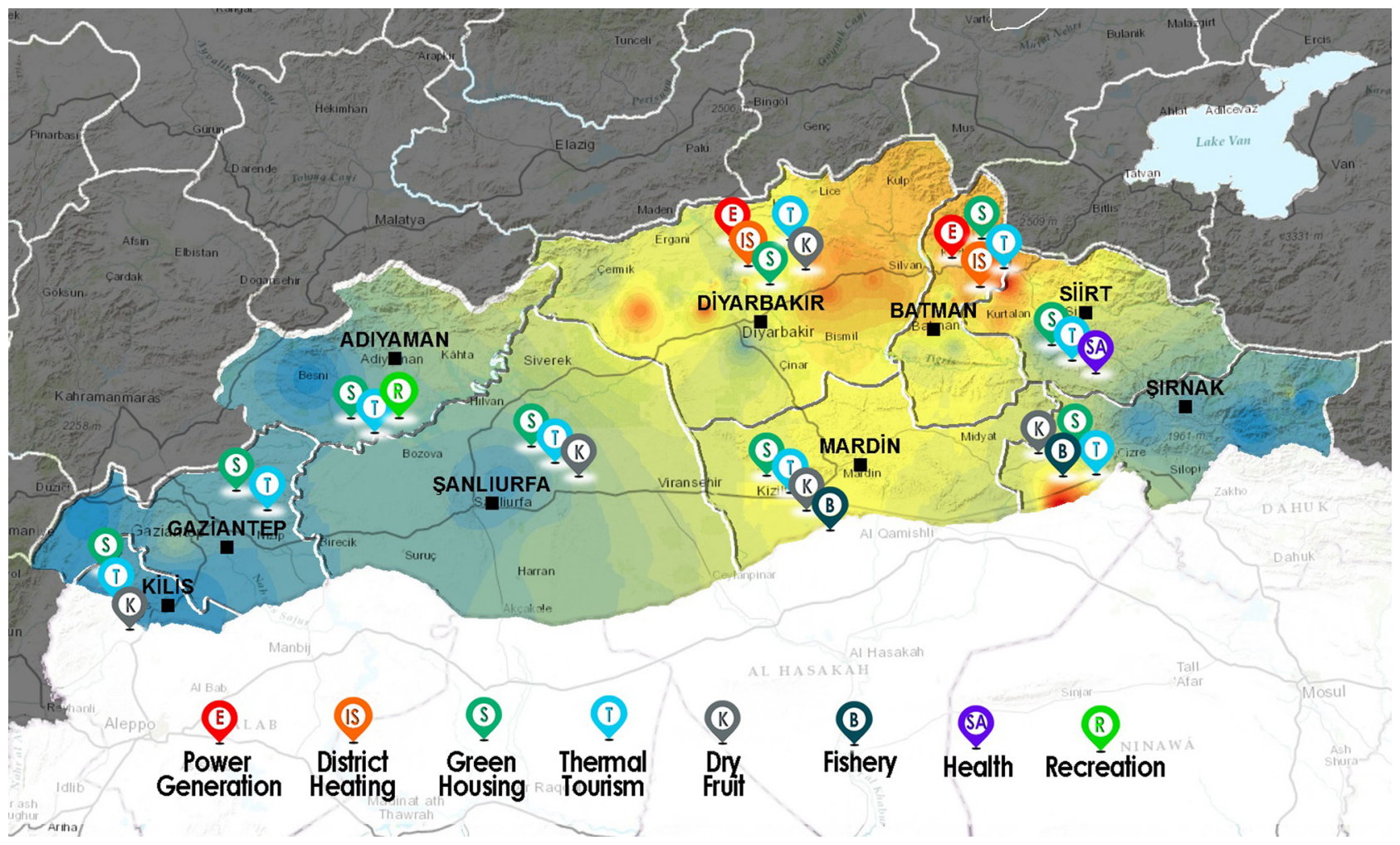

Fig. 14. The potential geothermal usage applications in GAP region.

between $1000 \mathrm{~m}$ and $4000 \mathrm{~m}$ (Fig. 13).

Chemical analyses of geothermal fluids can be used to estimate geothermal reservoir temperature. Chemical geothermometers depend on water-mineral equilibria (Nicholson, 1993b). Several geothermometry techniques have been developed to predict reservoir temperatures in geothermal systems (Fournier and Truesdell, 1973; Fournier, 1979; Fournier and Potter, 1982; Arnorsson et al., 1983; Giggenbach, 1988). All these techniques are based on the assumption that temperature-dependent water-mineral equilibria are attained in the reservoir. Baba et al., (2015a) used chemical geothermometry techniques to estimate the reservoir temperature of geothermal springs in the GAP geothermal region. According to the results of this study, the subsurface reservoir temperature of the GAP Region is in the range from $50^{\circ} \mathrm{C}$ to $200{ }^{\circ} \mathrm{C}$. This data also shows that the region has considerable potential in terms of geothermal energy. Although there is insufficient data on oil wells, it is clear that the geothermal potential in the area will increase even further if all data is evaluated. In the US, China, and Israel, studies are underway to utilize geothermal energy together with oil. The temperatures of existing and abandoned wells are suitable for power production, space heating, thermal tourism, greenhouses and drying facilities.

\section{Conclusions}

The extensive volcanism around the GAP region throughout the Late Cenozoic and recent times proves that there is an important heat source beneath the Anatolian Plate and Anatolian-Arabian subduction zone. Rising hot asthenosphere resulted locally and/or partial melting in the asthenosphere, continental crust, the Anatolian and Arabian lithospheric mantle. The heat source of the geothermal reservoirs is the volcanic rocks which are basaltic in a limited area and are homogeneously exposed in the Southeast Anatolia. The volcanism due to asthenospheric melting has generally reached the surface from cracks in the N-S direction. The neotectonic period volcanism, which emerged along cracks from different parts of the region and appeared as a cleft eruption, turned into a volcanic region around the Karacadağ. Micrograbens and local volcanic products are observed along the opening faults or normal faults. E-W-axis folds were formed as a result of compression in the N-S direction in the neotectonic period. In addition, thrust faults and compression related structures such as anticlines, accommodation zones of intersecting faults are important structures on the Arabian Plate for geothermal fluid circles in Southeastern Anatolia.

The hydrogeochemical properties of the geothermal fluid are variable from region to region. The geothermal fluids are of meteoric origin and have accumulated their heat during circulation in the fault systems. A great variety of chemical features is observed in the GAP geothermal system. The majority of the geothermal fluids are classified as Ca-Mg$\mathrm{SO}_{4}, \mathrm{Na}-\mathrm{HCO}_{3}, \mathrm{Na}-\mathrm{Cl}$ and $\mathrm{Ca}-\mathrm{SO}_{4}$ waters. Generally, the cold waters are of the water types $\mathrm{Ca}-\mathrm{Mg}-\mathrm{HCO}_{3}$ and $\mathrm{Ca}-\mathrm{HCO}_{3}$. The $\mathrm{Na}^{+}$and $\mathrm{K}^{+}$ concentration are increased in the deep geothermal fluid by deep circulation. The thermal spring water of lower temperature is of the Ca$\mathrm{Na}-\mathrm{HCO}_{3}$ type which is derived from the shallow reservoir. The Kozlu geothermal fluid (Batman) is $\mathrm{Na}-\mathrm{Cl}$ type water which is encountered in the high temperature and deep reservoirs. The Ilısu geothermal fluid is influenced by the dissolution of sulfate minerals which give rise to $\mathrm{Ca}$ $\mathrm{SO}_{4}$ water types.

Hot brine is produced along with the hydrocarbon product from oil wells in the GAP region. Several of these wells produce fluids at temperatures above $100{ }^{\circ} \mathrm{C}$ and have been projected to be capable of generating power for oN-Site consumption. Closely associated with volcanic activity are hot springs, gas vents, and other geothermal phenomena near hotspots.

Geothermal energy is one of the important energy sources to be developed in a rural region. The Southeastern Anatolia Region is located in the north of the Mesopotamia where the world's earliest civilization developed area is. These areas have many rural regions. It is possible to improve this important region with the use of geothermal sources. It is seen that the demand for geothermal energy in the region is increasing and at the same time, investments in geothermal energy are beginning to take place. It is possible to use different geothermal 
application such as power generation, district heating, thermal tourism and drying facilities (Fig. 14).

\section{Acknowledgments}

This work was supported by the GAP Regional Development Administration (GAP-RDA). We would like to thank the GAP RDA for their support during the work. We also thank Dr. Halldor Ármannsson and Gültekin Tarcan for the critical review of the manuscript.

\section{References}

Akkus, I., 2017. Why geothermal energy: importance of geothermal for Turkey. Chamber Geol. Eng. Mavi Gezegen 23, 25-39.

Akkuş, I., Akıllı, H., Ceyhan, S., Dilemre, A., Tekin, Z., 2005. Potential of Geothermal Energy in Turkey, MTA, Book Series Number: 201, Ankara. pp. 849.

Arnorsson, S., Gunnlaugsson, E., Svavarsson, H., 1983. The chemistry of geotherma waters in Iceland. III. Chemical geothermometry in geothermal investigations. Geochim. Cosmochim. Acta 47, 567-577.

Baba, A., 2015a. Application of geothermal energy and its environmental problems in Turkey. Int. J. Global Environ. Issues 14 (3/4), 2015.

Baba, A., 2015b. In: Biresselioğlu, M.E. (Ed.), Conservation of Natural Resources and Sustainable Management: Geothermal Energy, Perspective of Energy Security for Turkey. Energy Law Institute, pp. 85-100.

Baba, A., Ármannsson, H., 2006. Environmental Impact of the utilization of a geothermal area in Turkey. Energy Source (1), 267-278.

Baba, A., Akkus, İ., Saroğlu, F., Özel, N., Yesilnacar, M.İ, Nalbantçılar, M.T., Demir, M., Gökçen, G., Arslan, S., Dursun, N., ve Yazdani, H., 2015a. Geothermal Potential of GAP Region, GAP Project, Şanlıurfa.

Baba, A., Akkuş, İ., Şaroglu, F., Özel, N., Yeşilnacar, M.İ., Nalbantçılar, M.T., Demir, M.M., Gökcen, G., Arslan, S., Yazdani, H., Kuzgunkaya, E., Dursun, N., 2015b. Hydrogeochemical Properties of Geothermal System in the Southeastern Region (GAP). $3^{\text {rd }}$ Geothermal Resources symposium, Ankara, pp. 207-218 04-06 November 2015 (in Turkish).

Bolgi, T., 1964. Prospection Geology of Adiyaman Region. TPAO Archive No.32, Ankara.

Bozkurt, E., 2001. Neotectonics of Turkey - a synthesis. Geodin. Acta (14), 3-30.

Bozkurt, E., Mitwede, S.K., 2001. Introduction to the geology of Turkey-A synthesis. Int. Geol. Rev. (43)), 578-594.

Camp, R.T., 1963. In water and its impurities London: reinhold publishing corporation. Chapman \& Hall 136-137.

Craig, H., 1961. Isotopic variations in meteoric waters. Science 133, 1702-1703.

Dilek, Y., Sandvol, E., 2009. Seismic structure, crustal architecture and tectonic evolution of the Anatolian-African Plate Boundary and the Cenozoic Orogenic Belts in the Eastern Mediterranean Region, Geological Society, London. Special Publications 327 (21), 127-160.

Doğdu, M..S.., Kirmizitaş, H., 2006. Source of Karaali (Şanlıurfa-Yardımc1) geothermal system and estimation of reservoir temperature. J. Geol. Eng. 30 (1), 1-16.

Eisenlohr, T., 1995. Die Thermalwässer der Armutlu-Halbinsel (NW-Türkei) und deren Beziehung zu Geologie und Aktiver Tektonik. PhD. Dissertation, ETH-Zürich, Nr.11340. .

Emre, Ö., Duman, T.Y., Özalp, S., Elmac1, H., Olgun, Ş., 2012. 1:250.000 Scale Active Fault Map Series of Turkey, Diyarbakır (NJ37-11) and Ceylanpınar (NJ37-15) Quadrangles. Serial Number: 45. General Directorate of Mineral Research and Exploration, Ankara, Turkey.

Ercan, T., Saroğlu, F., Turhan, N., Matsuda, J.I., Dahide, U.T., Fujitani, T., Notsu, K. Bagirsakci, S., Aktimur, S., Can, B., Emre, O., Akcay, A.E., Manav, E., Gurler, H., 1991. The geology and petrology of the Karacadag volcanites. Bull. Geol. Soc. Turkey (6), 118-133.

Ertïrk, I.., 1999. Well completed report of K-5 in Urfa-Karaali. MTA, Ankara.

Erzenoğlu, Z., Özeke, H., 1984. Well Completed Report of Well Number I and II in Diyarbakır-çermik Geothermal Spa: MTA. 7652, 7, Ankara.

Eşder, T., Buzkiran, M., 1998. Geophysical (Resistivity Report) Report of Karaali (Sanlıurfa) Geothermal Site. JEO-MAGMA, Izmir.

Eşder, T., Tümer, M., 1997. Geophysical (Resistivity Report) Report of Karaali (Şanlıurfa) Geothermal Site With Belong to Govner of Sanlıurfa. JEO-MAGMA, Izmir

Faulds, N.H., Hinz, N.H., 2015. Favorable tectonic and structural settings of geothermal settings in the Great Basin region, Western USA: proxies for discovering blind geothermal systems. Proceedings, World Geothermal Congress 2015.

Faulds, J.E., Coolbaugh, M., Bouchot, V., Moeck, I., Oğuz, K., 2010. Characterizing structural controls of geothermal reservoirs in the Basin and range, USA, and western Turkey: developing successful exploration strategies in extended terranes. Proceedings of the World Geothermal Congress (April), 25-29 2010.

Fournier, R.O., 1979. A revised equation for the Na/K geothermometer. Geotherm. Resour. Council Trans. 5, 1-16.

Fournier, R.O., Potter, R.W.I.I., 1982. An Equation Correlating the Solubility of Quartz in Water from $25 \circ \mathrm{C}$ to $900 \circ \mathrm{C}$ at Pressures up to 10,000 Bars. Geochimica et Cosmochimica Acta, vol. 46. pp. 1969-1973.

Fournier, R.O., Truesdell, A.H., 1973. An empirical Na-K-Ca geothermometer for natural waters. Geochim. Cosmochim. Acta 37, 1255-1275.

GAP, 2014. South-Eastern Anatolia Project (GAP) Action Plan (2014-2018). Minister of Development, Turkey www.gap.gov.tr.

Gat, J.R., 1983. Precipitation, groundwater and surface waters: control of climate parameters on their isotopic composition and their utilisation as palaeo climatological tools. Proceedings, Palaeoclimates and Palaeowaters: A Collection of Environmental Isotope Studies (Proc. Advisory Group Mtg 3-12.

Giggenbach, W.F., 1988. Geothermal solute equilibria. Derivation of Na-K-Ca-Mg geoindicators. Geochim. Cosmochim. Acta 52, 2749-2765.

Günay, Y., Fourcadc, F., Dercourt, J., Azema, J., Kozlu, H., Bellier, J.P., Cordey, F., Cross, P., Wever, P., De-Enay, R., Lover, J.P., Vrielynck, B., 1990. Güneydoğu Türkiye'de Arap Plâtformunun Kuzey Kenan ve Bu Kenarın Mesozoyik'te Bir Tetis Okyanusal Alanına Geçişi: Stratigrafi-Paleocoğrafya: Türkiye 8. Petrol Kongresi Bildirileri, Ankara.

Haksal, A., 1981. Petrographie und Geochemie des Schildvulkans Karacadağ. Ph.Dr. thesis. Hamburg University, Germany.

Hall, R., 1976. Ophiolite emplacement and the evolution of the Taurus suture zone, southeastern Turkey. Geol. Soc. Am. Bull. 87, 1078-1088.

Ketin, İ., 1983. Overview of Turkey geology. İTÜ, Book. Number, 32, İstanbul. pp. 309.

Mazor, E., 2004. Applied Chemical and Isotopic Groundwater Hydrology, $3^{\text {rd }}$ edition. Marcel Dekker, Inc, New York.

Mertoğlu, O., 2010. Possible Theoretical Potential and Preliminary Evaluation Report of Şanliurfa Karaali Geothermal Site. Govner of Şanlıurfa, Turkey.

Nicholson, K., 1993a. Geothermal Fluids: Chemistry and Exploration Techniques. Springer, Berlin, Germany.

Nicholson, K., 1993b. Geothermal Fluids Chemistry and Exploration Techniques. Springer-Verlag, Berlin.

Özel, N., 2010. Investigation source of Diyarbakır (Çermik) and Şanlıurfa (Karaali) geothermal resources. Çukurova University, Adana Ms. Thesis.

Özel, N., Bekişoğlu, Ş., 2002. Evaluation of Geothermal Resources for Greenhouse and Thermal Tourism in Southeastern Anatolia Region (GAP). CESAV, Publication No.1, Ankara, pp. 158.

Pearce, J.A., Bender, J.F., De Long, S.E., Kidd, W.S.F., Low, P.J., Güner, Y., Şaroğlu, F., Yilmaz, Y., Moorbath, S., Mitchell, J.J., 1990. Genesis of collision volcanism in Eastern Anatolia Turkey. J. Volcanol. Geotherm. Res. 44, 189-229.

Perinçek, D., 1979. The Geology of Hazro-Korudağ-Çüngüş-Maden-Ergani-Elazı̆̆- Malatya Area: Guide Book. T.J.K. Yayını. pp. 33s.

Perincek, D., 1980. The Tectonic Evolution of the Northern Arabian Continent and Its Effect on Sedimentation. $5^{\text {th }}$ Turkish Petrolium Congress, Turkey, pp. 77-93.

Perinçek, D., Özkaya, I., 1981. Tectonic evolution of the northern edge of the Arabian Plate, Hacettepe University. Bull. Earth Sci. (8), 91-101.

Rigo De Righi, M., Cortesini, A., 1964. Gravity tectonics in Foothills Structure Belt of Southeast Turkey. AAPG Bult 48 (12), 1911-1937.

Robertson, A.H.F., Aktaş, A.H.F., 1984. The Maden complex, SE Turkey: evolution of a neotethyan active margin. In: Robertson, A.H.F., Dixon, J.E. (Eds.), the Geological Evolution of the Eastern Mediterranean. Blackwell, Oxford, pp. 375-402.

Şaroğlu, F., 1985. Geological and Structural Evolution of the Eastern Anatolia During the Neotectonic Period: İstanbul University. Ph. Dr. Thesis.

Saroğlu, F., Emre, Ü., 1987. General Properties of Karacadağ Volcanics and It's the Location in the Southeast Anatolian Autokonton: $7^{\text {th }}$ Turkish Petrolium Congress, Proceeding Book. pp. 384-391.

Saroğlu, F., Yilmaz, Y., 1987. Geological evolution of the Eastern Anatolia during the neotectonic period and plain models. MTA J. 107, S.73-94.

Sayın, M., Eyüpoğlu, S.Ö., 2005. Determination of the local meteoric Water lines using stable isotope contents of precipitation in Turkey (in Turkish). Proceedings, II. National Symposium of Isotopic Methods in Hydrology 323-344.

Schmidt, G.C., 1964. Permien and Mesozoic formation around Harbol Region (TürkiyeIrak Boundary)MTA Journal. MTA J. 62 Ankara.

Sengör, A.M.C., 1980. Principles of Turkey's neotectonics, geological survey of Turkey. Conference Series 2, 40.

Şengör, A.M.C., Burke, K., 1978. Relative timing of rifting and volcanism on earth and its tectonic implications. Geophys. Res. Lett. 5https://doi.org/10.1029/ GL005i006p00419. ISSN: 0094-8276.

Şengör, A.M.C., Y1lmaz, Y., 1981. Tethyan evolution of Turkey: a plate tectonic approach. Tectonophysics 75, 181-224.

Sengör, A.M.C., Y1lmaz, Y., 1983. Tethyan Evolution of Turkey: An Approach in Terms of Plate Tectonic. Geological Society of Turkey, A Special Series of Geosciences, vol.1 Ankara (in Turkish).

Sengör, A.M.C., Satir, M., Akkök, R., 1984. Timing of tectonic events in the Menderes Massif, western Turkey: implications for tectonic evolution and evidence for PanAfrican basement in Turkey. Tectonics 4 (693), 707.

Şengör, A.M.C., Görür, N., Şaroğlu, F., 1985. Strike-slip faulting and related basin formation in zones of tectonic escape: Turkey as a case study. In: In: Biddle, K.T., Christie-Blick, N. (Eds.), Strike-Slip Faulting and Basin Formation: Society of Economic Paleontologists and Mineralogists, Special Publication, vol. 37. pp. $227-264$.

Seyitoğlu, G., Esat, K., Kaypak, B., 2017. The neotectonics of southeast Turkey, northern Syria, and Iraq: the internal structure of the Southeast Anatolian Wedge and its relationship with recent earthquakes. Turk. J. Earth Sci. 26, 105-126.

Simsek, S., 1997. Geothermal potential in northwestern Turkey. In: Schindler, C., Pfister, M. (Eds.), Active Tectonics of Northwestern Anatolia, the Marmara Poly-Project. Vdf Hochschulverlag. AG an der ETH, Zurich, pp. 111-123.

Simsek, S., Yıldırım, N., Simșek, Z.N., Karakuș, H., 2002. Changes in geothermal resources at earthquake regions and their importance. Proceedings of Middle Anatolian Geothermal Energy and Environmental Symposium. pp. 1-13.

Sungurlu, O., 1972. Geology between Gölbaş1-Gerger Fields, VI. Region, TPAO Report, vol. 802.

Sungurlu, O., 1974. North field geology of IV. Region, $1^{\text {st }}$ Turkish Petrolium Congress Proceeding Book, Ankara. pp. 85-107.

Turan, M., 1995. The geodynamic evolution of the Eastern Taurus properties Elazığ 
Region, Firat University. J. Sci. Eng. 2 (79), 177-199.

Uzel, Ö.F., Kalkan, I., 1992. Hydrogeology of Sanlıurfa-Yardımc1-Karaali Spa. MTA Report, pp. 89419.

Uzelli, T., Baba, A., Mungan, G.G., Dirik, R.K., H, S.özbilir, 2017. Conceptual model of the Gülbahçe geothermal system, Western Anatolia, Turkey: based on structural and hydrogeochemical data. Geothermics $68,67-85$.

Wilson, H.H., Krummenacher, R., 1957. Geology and Oil Prospects of the Gaziantep Region; Available Information in Technical Fields of NV Turkse Shell, 1963 Petroleum Activites In Turkey. Petroleum Administration Publication Bult, pp. 8. Yazgan, E., 1984. Geodynamic evolution of the Eastern Taurus Region. In: Tekeli, O., Göncüoğlu, M.C. (Eds.), The Geology of the Taurus Belt, pp. 199-208.

Yazgan, E., Chessex, R., 1991. Geology and Tectonic Evolution of the Southeastern
Taurides Inthe Region of Malatya. T.P.J.D. Bült, pp. 1-42 3/1

Yllmaz, Y., 1981. Rift, alakogen, impactogen in Turkey. Gelogical survey of Turkey. Conference Serisi 17.

Yilmaz, Y., 1993. New evidence and model on the evolution of the southeast Anatolian orogen. Geol. Soc. Am. Bull. 105, 252-271.

Yllmaz, Y., Yiğitbaș, E., 1990. Different ophiolithic in SE of anatolia- metamorphic associations and their role in geological evolution; 8.Turkish petroleum congress. Proceeding Book. pp. 128-140.

Yücel, B., 1989a. Geology and Geothermal Energy Potential of Cermik (Diyarbakır) Region. MTA Report, Ankara, pp. 8744.

Yücel, B., 1989b. Geology and Geothermal Energy Potential of Siirt-Billoris Spa Region. MTA Report, Ankara, pp. 8750. 